\title{
Effect of biodiesel-derived impurities (acetic acid, methanol and potassium hydroxide) on the aqueous phase reforming of glycerol
}

\author{
J. Remón, J. Ruiz, M. Oliva, L. García *, J. Arauzo
}

Thermochemical Processes Group (GPT), Aragón Institute for Engineering Research (I3A), Universidad de Zaragoza. Mariano Esquillor s/n, E-50018 Zaragoza, Spain. *Corresponding author. Tel: +34 976 762194; Fax: +34 976 761879; e-mail: $\underline{\text { luciag@unizar.es }}$

\begin{abstract}
This work analyses the influence of the presence of varying amounts of three common biodiesel-derived impurities $\left(\mathrm{CH}_{3} \mathrm{OH}, \mathrm{CH}_{3} \mathrm{COOH}\right.$ and $\left.\mathrm{KOH}\right)$ on the aqueous phase reforming of glycerol at $220^{\circ} \mathrm{C}$ and 44 bar using a $\mathrm{Ni}-\mathrm{La} / \mathrm{Al}_{2} \mathrm{O}_{3}$ catalyst. The experiments were planed according to a factorial $2^{\mathrm{k}}$ design and analysed by means of an analysis of variance (ANOVA) test to identify the effect of each impurity and all possible binary and ternary combinations. The presence of $\mathrm{CH}_{3} \mathrm{OH}$ in the solution decreased the glycerol conversion. $\mathrm{CH}_{3} \mathrm{COOH}$ and $\mathrm{KOH}$ decreased and increased the gas production, respectively, but they did not alter the conversion of glycerol. These variations were the consequence of the changes in the $\mathrm{K}^{+} / \mathrm{OH}^{-}$and $\mathrm{K}^{+} / \mathrm{H}^{+}$ratios of the solutions that occur with the addition of the impurities. Catalyst deactivation took place under acidic conditions due to the loss of part of the active phase of the catalyst through leaching; the lower the $\mathrm{pH}$ of the solution, the greater was the deactivation of the catalyst. The gas phase was made up of $\mathrm{H}_{2}, \mathrm{CO}_{2}, \mathrm{CO}$ and $\mathrm{CH}_{4} \mathrm{KOH}$ exerted the greatest influence on the gas composition, increasing $\mathrm{H}_{2}$ production due to the greater gas
\end{abstract}


production and the lower $\mathrm{H}_{2}$ consumption in the hydrogenation reactions under basic conditions. The liquid phase was made up of aldehydes, monohydric and polyhydric alcohols, $\mathrm{C} 3$ and $\mathrm{C} 4$ ketones and esters. $\mathrm{CH}_{3} \mathrm{OH}$ increased the proportion of monohydric alcohols, while $\mathrm{KOH}$ did not greatly vary the liquid product distribution obtained with pure glycerol. $\mathrm{CH}_{3} \mathrm{COOH}$ promoted dehydration reactions, favoured under acidic conditions, leading to a decrease in the proportion of monohydric alcohols and an increase in the relative amount of C3-ketones.

Keywords: crude glycerol, aqueous phase reforming, acetic acid, methanol, potassium hydroxide 


\section{Introduction}

Renewable biomass sources are currently of considerable interest because they provide an interesting route for the production of chemicals and energy [1, 2]. Among the various biomass feedstocks, glycerol is an attractive resource due to its widespread availability as a by-product formed in biodiesel production (1 $\mathrm{kg}$ of crude glycerol is yielded with the production of $10 \mathrm{~kg}$ of biodiesel). Glycerol obtained in biodiesel manufacturing has become a cheap resource for which new valorisation routes need to be developed. In addition, the recent rapid growth of the biodiesel industry could create a surplus of glycerol unable to be absorbed by its current market, which may cause economic and environmental problems. This would hamper the development of the biodiesel industry [3].

A promising strategy for the valorisation of this biodiesel-derived glycerol is aqueous phase reforming (APR). APR is a catalytic process carried out at quite low temperatures and moderate pressures, producing different chemicals (gases and liquids) from an organic feedstock. The gas phase consists of a gas with a high $\mathrm{H}_{2}$ content while the liquid phase is a complex mixture of different organic compounds such as alcohols, ketones, acids, esters, paraffins, aldehydes and other oxygenated compounds in water. The yields and compositions of the gas and liquid phases depend on the operating conditions of the process, the catalyst type and the nature of the feed [4-7].

Works dealing with the aqueous phase reforming of crude glycerol are extremely scarce $[4,7-9]$ and the vast majority of the publications in the literature are focused on understanding the effect of the catalyst type and the operating conditions during the APR of pure glycerol. The catalysts used in the process are noble metals based on Pt [9- 
14], Ni [9, 10, 14-18], Pt-Ni, Cu, Co or Ru [7, 10, 14, 16, 19] supported on different oxides such as $\mathrm{Al}_{2} \mathrm{O}_{3}, \mathrm{ZrO}_{2}, \mathrm{MgO}, \mathrm{SiO}_{2}, \mathrm{CeO}_{2}$, or carbon $[4,20]$ and modified, in some cases, with promoters such as $\mathrm{La}, \mathrm{Ce}, \mathrm{Mg}$ and $\mathrm{Zr}$. The influence of the operating variables (temperature, pressure, glycerol concentration, flow rate, catalyst loading and hourly space velocity) on the process has been studied using reagent grade glycerol in both batch and flow reactors $[12,17,19,21,22]$.

The studies reported to date provide valuable information on the APR process for pure glycerol, but the impurities accompanying the crude glycerol obtained from the biodiesel industry are expected to significantly reduce the yield and efficiencies of the APR process and to deactivate the catalysts. Crude glycerol consists not only of glycerol but also of many other chemicals such as methanol, soap, catalyst, salts and non-glycerol organic matter [3]. Therefore, it is very important to understand how the presence of the most common biodiesel-derived impurities affects the process for the development of this valorisation route.

The comparisons between the results obtained with crude and reagent grade glycerol when subjected to the same valorisation process have shown that the efficiencies of the processes depend on the glycerol used. These results have been compared for valorisation processes including steam reforming, supercritical water reforming and aqueous phase reforming. For steam reforming, Slinn et al. [23] found that the conversions and yields with crude glycerol were $70 \%$ of those obtained with pure glycerol, Dou et al. [24] reported that crude glycerol conversions were slightly higher than those of pure glycerol under the same reaction conditions, and Valliyappan et al. [25] indicated that the production of hydrogen and the yield to gas from crude glycerol 
were higher than those from pure glycerol. Remón et al. [26] analysed the effect of $\mathrm{CH}_{3} \mathrm{OH}, \mathrm{CH}_{3} \mathrm{COOH}$ and $\mathrm{KOH}$ during glycerol steam reforming in a fluidised bed reactor. It was found that the three compounds had a significant impact on product distribution (gas, liquid and solid) in carbon basis; the composition of the gas being little affected. $\mathrm{CH}_{3} \mathrm{OH}$ alone did not alter the results obtained with pure glycerol. In contrast, $\mathrm{CH}_{3} \mathrm{COOH}$ and $\mathrm{KOH}$ decreased the initial production of gases, especially for $\mathrm{KOH}$. However, the progressive accumulation of $\mathrm{KOH}$ inside the reactor exerted a positive catalytic effect on the gasification of this char, augmenting the gas production over time. For supercritical water reforming, it was reported that the use of crude glycerol led to higher catalyst deactivation than that obtained with pure glycerol [27].

To the best of the authors' knowledge, there are only three studies currently available on aqueous phase reforming of crude glycerol, and only two of them analyse the effect of some biodiesel-derived impurities on the process. Lehnert and Claus [9] reported the aqueous phase reforming of pure and crude glycerol using different Pt-based catalysts at $250{ }^{\circ} \mathrm{C}$ and 20 bar Argon. They found a lower $\mathrm{H}_{2}$ selectivity and a higher catalyst deactivation with crude glycerol due to the presence of $\mathrm{NaCl}$ salts in the solution. King et al. [4] studied the aqueous phase reforming of a $10 \mathrm{wt} . \%$ glycerol solution containing $\mathrm{KOH}$ using different Pt and Re catalysts supported on carbon. The addition of 0.1 wt.\% of $\mathrm{KOH}$ to the solution until reaching a $\mathrm{pH}$ of 12 increased both the glycerol conversion and the $\mathrm{H}_{2}$ production. It was reported that the $\mathrm{pH}$ of the solution exerted a great influence on the selectivity of the process. Boga et al. [8] studied the aqueous phase reforming of glycerol and crude glycerol, establishing a comparison between both feedstocks and analysing the effect of some of the impurities commonly found in crude glycerol. The crude glycerol solution was made up of 6.85 wt.\% glycerol, 1.62 wt.\% 
soaps, 1.55 wt. $\%$ methanol and 0.07 wt. $\%$ esters. The use of this crude glycerol solution resulted in a dramatic drop in APR activity compared to the corresponding $6.85 \mathrm{wt} . \%$ pure glycerol solution. The results obtained with different synthetic mixtures revealed that $\mathrm{Na}$ salts of fatty acids had a much more pronounced negative influence than $\mathrm{NaOH}$ and greatly inhibited $\mathrm{H}_{2}$ formation. Stearic acid, long chain aliphatics and olefins were shown to be formed and to be involved in the deactivation of the catalyst.

This scenario suggests that the cost-effective reduction of some of the troublesome impurities present in crude glycerol, such as fatty acid methyl esters, (FAMES) and soaps, before the valorisation of this feedstock might be beneficial for increasing the yields and efficiencies of glycerol valorisation processes. This cost-effective strategy consists of the separation of the FAMES and the elimination of the soaps present in the solution by an initial acidification, normally with acetic, sulphuric or phosphoric acid $[3,28]$, and a subsequent liquid-liquid extraction with a polar solvent. The work of Manosak et al. [3] provides an in-depth study of this purification method.

Given this background, the objective of this work is to study the effect on the APR process of the presence of three common biodiesel-derived glycerol impurities that may be present in the glycerol obtained from the biodiesel industry (crude and/or refined glycerol): acetic acid, potassium hydroxide and methanol. Acetic acid is an organic acid that can be used in glycerol neutralisation without poisoning the catalysts that are habitually used in APR, as occurs when using $\mathrm{H}_{2} \mathrm{SO}_{4}$ due to the presence of $\mathrm{S}$, and that can contribute to $\mathrm{H}_{2}$ formation. Potassium hydroxide is commonly employed as a homogeneous catalyst in biodiesel production. Methanol is an alcohol generally used in biodiesel production as well as during the glycerol purification step [29]. Specifically, 
this work provides information about the effect of the presence in a glycerol/water solution of the three impurities considered alone and all the binary and ternary combinations. This strategy not only allows a comparison to be made between pure and crude glycerol, but also leads to an understanding of the individual and synergetic effects on the process of the presence of these impurities in crude glycerol.

The effect of the presence of these impurities has been investigated in a flow reactor at $220^{\circ} \mathrm{C}$ and 44 bar using a $\mathrm{Ni}-\mathrm{La} / \mathrm{Al}_{2} \mathrm{O}_{3}$ catalyst, analysing how and to what extent the glycerol conversion, the product distribution in carbon basis (carbon converted to gas and liquid products) and the compositions of the gas and liquid phases are affected by the presence of these impurities. Given that the combined effect of the presence in crude glycerol of methanol, acetic acid and potassium hydroxide has never been studied before, and considering the limited number of studies dealing with crude glycerol, this work represents a novel investigation for gaining a better understanding of the aqueous phase reforming of crude glycerol.

\section{Experimental}

\subsection{Experimental system}

The experiments were carried out in a small bench scale continuous unit for 3 hours employing a Ni-La/ $/ \mathrm{Al}_{2} \mathrm{O}_{3}$ catalyst. The catalyst was prepared by coprecipitation, having $28 \%$ (relative atomic percentage) of $\mathrm{Ni}$ expressed as $\mathrm{Ni} /(\mathrm{Ni}+\mathrm{Al}+\mathrm{La})$, an atomic $\mathrm{La} / \mathrm{Al}$ ratio of 0.035 and a BET surface area of $187 \mathrm{~m}^{2} / \mathrm{g}$. The experimental rig used in the experiments was a microactivity unit designed and built by PID (Process Integral Development Eng \& Tech, Spain). It consists of a stainless steel tubular reactor with an 
inner diameter of $9 \mathrm{~mm}$, heated up by means of an electric furnace [30]. The system pressure is reached with the aid of a micrometric valve that automatically adapts its position with the help of a rotor. A pressure gauge, located at the exit of the reactor, measures the pressure of the reaction section. A PDI control system is used to keep the reactor pressure constant during the experiments. The aqueous solutions of glycerol are fed into the reactor by means of a high performance liquid chromatography (HPLC) pump (Gilson, model 307). The reaction products (gas and liquids) leave the reactor from its upper part, pass through the valve where they are depressurised, and arrive at the condensation system. This system consists of several condensers where the liquid products are separated from the gas mixture at intervals of $1 \mathrm{~h}$ to analyse the evolution over time of the liquid phase. The gas mixture is made up of $\mathrm{N}_{2}$, used as an internal standard, and the different gaseous products formed during the aqueous phase reforming reaction. An Agilent M3000 micro chromatograph equipped with thermal conductivity detectors (TCD) was used for the online analysis of the gas phase. The liquid fractions were collected and analysed offline with a gas chromatograph (Agilent 7890 GCsystem, model G3440A) equipped with Flame Ionization (FID), and Mass Spectrometry (MS) detectors. A schematic diagram of the experimental system is shown in Figure 1.

\subsection{Experimental design and data analysis}

The influence of the presence of up to $5 \mathrm{wt} . \%$ of $\mathrm{CH}_{3} \mathrm{OH}, 3 \mathrm{wt} . \%$ of $\mathrm{CH}_{3} \mathrm{COOH}$ and 2.8 wt.\% of $\mathrm{KOH}$ in a $30 \mathrm{wt} . \%$ glycerol/water solution has been experimentally investigated at 44 bar and $220{ }^{\circ} \mathrm{C}$ with a $\mathrm{Ni}-\mathrm{La} / \mathrm{Al}_{2} \mathrm{O}_{3}$ catalyst using a space-time defined as the mass of catalyst/mass flow rate of glycerol $\left(\mathrm{W} / \mathrm{m}_{\text {glycerol }}\right)$ ratio of $25 \mathrm{~g}$ catalyst $\mathrm{min} / \mathrm{g}$ glycerol. The intervals of variation of these compounds in the mixture 
were chosen having regard to the range that these impurities could have in crude and refined glycerol solutions $[3,31]$.

The response variables studied were the global glycerol conversion (X gly), carbon conversion to gases, liquid and solid products (CC gas, CC liq and CC sol) as well as the composition of the gas $\left(\mathrm{N}_{2}\right.$ and $\mathrm{H}_{2} \mathrm{O}$ free, vol.\%) and liquid (relative chromatographic area free of water and un-reacted glycerol, \%). The CC sol was calculated by difference. Table 1 summarises the response variables and the analytical methods used for their calculation.

To study the effect of the presence of the individual impurities as well as the effect of all their possible binary and ternary combinations ( 2 or 3 impurities), the experiments were designed using a $2^{\mathrm{k}}$ factorial design, where $\mathrm{k}$ indicates the number of factors studied (in this case 3 impurities) and $2^{\mathrm{k}}$ represents the number of runs (in this case 8). In addition, three replicates at the centre point (centre of the variation interval of each factor) were carried out in order to evaluate both the experimental error and the curvature shown by the evolution of each variable, i.e. whether or not this evolution is linear within the experimental range studied. Table 2 shows the composition (in actual and codec factors), the $\mathrm{S} / \mathrm{C}$ ratio and the $\mathrm{pH}$ of the $30 \mathrm{wt} . \%$ glycerol solutions employed in the experiments according to the $2^{\mathrm{k}}$ design. The lower and upper limits of all the factors (the concentration of $\mathrm{CH}_{3} \mathrm{COOH}, \mathrm{CH}_{3} \mathrm{OH}$ and $\mathrm{KOH}$ ) were normalised from -1 to 1 (codec factors). This codification permits that all factors vary within the same interval and helps to investigate their influence in comparable terms. 
First of all, the evolution over time was studied. For each experiment, the results are divided into three intervals. Each interval corresponds to the average value of the studied response variables obtained during the first, second and third hour of the experiment. All these values (three per experiment) have been compared using a oneway analysis of variance (one-way ANOVA) and Fisher's least significant difference (LSD) test, both with 95\% confidence. The results of the ANOVA analyses are provided as p-values. P-values lower than 0.05 indicate that at least two values are significantly different. Furthermore, the LSD test was used to compare pairs of data, i.e. either between two intervals of the same experiment or between two intervals of two different experiments. The results of the LSD tests are presented graphically in the form of LSD bars. To ensure significant differences between any pair of data, their LSD bars must not overlap.

Secondly, the effect of the impurities was studied considering the results corresponding to the first hour using a statistical analysis of variance (one-way ANOVA) test with $95 \%$ confidence. This strategy means that it is unnecessary to include the effect of the variations with time of the different response variables in the analysis. The ANOVA analyses evaluate whether the effect of the impurities, their interactions and the curvature have a significant influence or not on the response variables. In addition, the cause-effect Pareto principle was also used to calculate their relative importance.

\subsection{Possible reaction network during the aqueous phase reforming of glycerol}

A plausible reaction pathway for the aqueous phase reforming of glycerol is shown in

Figure 2. The reaction network includes the formation of gases and liquid products. 
Three possible parallel routes explain the formation of intermediate liquids: glycerol dehydration to 1-hydroxypropan-2-one (A) [4, 5, 19, 32-35] and/or to 3hydroxypropanal (B) [5, 33-35] and/or glycerol dehydrogenation to 2,3dihydroxypropanal (C) $[4,5,19,32-35]$. Gases, mainly $\mathrm{H}_{2}$ and $\mathrm{CO}$, are produced by the thermal decomposition and/or reforming reactions of the glycerol and all the liquid intermediates (Eq.1) as well as by all the decarbonylation reactions that release CO. In addition, the water gas shift reaction (Eq.2) and methanation reactions (Eq.3-4) are also possible, explaining the presence of $\mathrm{CO}_{2}$ and $\mathrm{CH}_{4}$ in the gas phase [4, 5, 19, 32-35].

$$
\begin{aligned}
& \mathrm{C}_{\mathrm{n}} \mathrm{H}_{\mathrm{m}} \mathrm{O}_{\mathrm{k}}+(\mathrm{n}-\mathrm{k}) \mathrm{H}_{2} \mathrm{O} \Leftrightarrow \mathrm{n} \mathrm{CO}+(\mathrm{n}+\mathrm{m} / 2-\mathrm{k}) \mathrm{H}_{2} \\
& \mathrm{CO}+\mathrm{H}_{2} \mathrm{O} \Leftrightarrow \mathrm{CO}_{2}+\mathrm{H}_{2} \\
& \mathrm{CO}+3 \mathrm{H}_{2} \Leftrightarrow \mathrm{CH}_{4}+\mathrm{H}_{2} \mathrm{O} \\
& \mathrm{CO}_{2}+4 \mathrm{H}_{2} \Leftrightarrow \mathrm{CH}_{4}+2 \mathrm{H}_{2} \mathrm{O}
\end{aligned}
$$

\subsubsection{Formation of products via 1-hydroxypropan-2-one: route A}

1-hydroxypropan-2-one can undergo further hydrogenation to produce propane-1,2-diol $[4,5,33-35]$ (the preferred and most reported route) and/or dehydration to form acryaldehyde [33], which can be transformed into propionic acid [33]. Propane-1,2-diol can subsequently be dehydrated to form propan-2-one and/or propionaldehyde, which can be hydrogenated to propan-2-ol and propan-1-ol, respectively [33]. Afterwards, these two chemicals can be further transformed into light alkanes, such as propane and butane, respectively, via Cannizzaro type reactions, organic rearrangement and dehydration, decarboxylation and hydrogenation reactions [5, 33-35]. Ethanol might be 
formed from the cracking and hydrogenation of propan-2-ol [5].

\subsubsection{Formation of products via 3-hydroxypropanal: route B}

The presence of 3-hydroxypropanal in the liquid product has not been detected in the vast majority of works dealing with the aqueous phase reforming of glycerol. This indicates that dehydration forming 1-hydroxypropan-2-one is more likely to occur and/or that 3-hydroxypropanal may be instantaneously converted into other products in subsequent reactions. These reactions produce 3-hydroxypropionic acid, acetaldehyde and formaldehyde via the retro-aldol reaction [33], and/or propane-1,3-diol [32, 33] via hydrogenation. Propane-1,3-diol can be further dehydrated to produce propionaldehyde [33].

2.4.3 Formation of products via 2,3-dihydroxypropanal: route $C$

2,3-dihydroxypropanal can be transformed into 2,3-dihydroxypropionic acid, dehydrated to form 2-oxopropanal and/or decarbonylated to produce ethane-1,2-diol. Subsequently, 2-oxopropanal can be further hydrogenated to form propane-1,2-diol. Additionally, 2-hydroxyacetaldehyde can be obtained from the dehydrogenation of ethane-1,2-diol and might lead to the formation of methanol by decarbonylation $[4,5]$. In addition, acetaldehyde and ethanol can be produced from the dehydration and the dehydration/hydrogenation of ethane-1,2-diol, respectively [4, 5, 34]. Acetaldehyde can subsequently be transformed into acetic acid and/or methane, while ethene and ethane can be produced from ethanol $[4,5,34]$. 


\section{Results}

\subsection{Glycerol conversion and carbon distribution (CC gas, CC liq and CC sol)}

Figure 3 displays the carbon conversion to gas and liquid (CC gas, CC liq) as well as the global glycerol conversion (X gly). The statistical analysis reveals significant differences between the results obtained in the experiments for the $\mathrm{CC}$ gas, $\mathrm{CC}$ liq and $\mathrm{X}$ gly (p-values $<0.001$ ). Specifically, they vary by $12-32 \%, 33-70 \%$ and $47-92 \%$, respectively. The effect of the impurities on the $\mathrm{CC}$ sol was not significant ( $\mathrm{p}$-value > $0.05)$ and in all the experiments the $\mathrm{CC}$ sol was lower than $5 \%$.

The evolution over time of these variables shows significant reductions in the $\mathrm{X}$ gly and the $\mathrm{CC}$ liq, while minimal variations take place for the $\mathrm{CC}$ gas. These developments suggest a possible deactivation of the catalyst, which very interestingly does not affect gas production. Exceptionally, run 5, which contains $\mathrm{KOH}$ as an impurity, shows a steady evolution for the $\mathrm{X}$ gly and the $\mathrm{CC}$ liq. $\mathrm{KOH}$ has been reported to have a positive catalytic effect $[36,37]$ on the reforming of different oxygenates. In addition, King et al. [4] reported that the addition of $\mathrm{KOH}$ to the solution during the aqueous phase reforming of glycerol favours base-catalysed reactions, increasing glycerol conversion. Therefore, the presence of $\mathrm{KOH}$ in the solution can compensate for the deactivation of the catalyst in the process due to its own intrinsic catalytic activity.

The effect on the deactivation of the catalyst of the presence in the glycerol solution of $\mathrm{CH}_{3} \mathrm{COOH}, \mathrm{CH}_{3} \mathrm{OH}$ and $\mathrm{KOH}$ can be investigated by analysing the evolution over time of the $\mathrm{X}$ gly in the experiments. The addition of $\mathrm{CH}_{3} \mathrm{COOH}$ (run 2), $\mathrm{CH}_{3} \mathrm{OH}$ (run 3) individually or mixed (run 4) to the glycerol solution increases the reduction over time for the X gly compared to that obtained with glycerol (run 1). Interestingly, the decay in 
the $\mathrm{X}$ gly over time for runs $6-11$ is less pronounced than that observed for runs 2-4 due to the presence of $\mathrm{KOH}$ in the solution. In addition, this decay in the $\mathrm{X}$ gly over time also occurs for runs 6 and 7 in spite of the presence of $\mathrm{KOH}$ in the solution, as some interactions between the impurities can take place [26]. These solutions contain $\mathrm{CH}_{3} \mathrm{COOH}$ or $\mathrm{CH}_{3} \mathrm{OH}$, which can transform $\mathrm{KOH}$ into $\mathrm{CH}_{3} \mathrm{COOK}$, a colourless liquid at standard temperature and pressure, or into $\mathrm{CH}_{3} \mathrm{OK}$, a white to yellow hydroscopic powder [38], thus decreasing the positive catalytic effect of $\mathrm{KOH}$. Additionally, the complete elimination of $\mathrm{KOH}$ is not possible for runs 8 and 9-11 due to the different amounts of impurities, and consequently the positive catalytic effect of $\mathrm{KOH}$ in the process softens the decay in the $\mathrm{X}$ gly over time. These interactions between impurities will be further discussed in connection with the results obtained during the first hour of reaction, making use of a statistical analysis.

To gain a better insight into catalyst deactivation, the carbon deposited on the spent catalysts was determined by elemental analysis. Also, some liquid condensates were analysed by ICP to elucidate the cause of catalyst deactivation, whether coking and/or metal active phase leaching. The elemental analysis revealed that the carbon deposited on the catalyst surface was lower than $5 \mathrm{mg} \mathrm{C} / \mathrm{g}$ catalyst g organics reacted (to form both gases and liquid products) for all the experiments, which indicates that coke formation is minimal under the operating conditions tested in this work. In a previous work, where a similar $28 \mathrm{wt} . \%$ Ni-based catalyst was used for the catalytic reforming of the aqueous fraction of bio-oil [39], steady conversions were achieved with an amount of $\mathrm{C}$ deposited on the catalyst of around $10 \mathrm{mg} \mathrm{C} / \mathrm{g}$ catalyst $\mathrm{g}$ organic reacted, which is in the same range as that obtained in this work. This suggests that catalyst deactivation by coking is not the main process responsible for the decreases observed in the $\mathrm{X}$ gly 
over time. The analysis of the liquid condensates by ICP revealed the presence of $\mathrm{Ni}, \mathrm{Al}$ and La in some of them, which indicates that the catalyst active phase and support can be lost by leaching during reaction. Table 3 lists the relative amounts $(\%)$ of $\mathrm{Ni}, \mathrm{Al}$ and La leached from the catalyst to the liquid phase during the APR reaction with respect to the original amount of these metals initially loaded in the catalyst. In addition, a numerical quantification for the decay observed in the $\mathrm{X}$ gly over time is also provided.

The greatest amounts of $\mathrm{Ni}$ and La leached from the catalyst occur for runs 1 and 4, which accounts for the experimental reductions observed in the X gly for these two experiments. Interestingly, run 5 shows a loss in the amount of $\mathrm{Al}$ in the catalyst, while no signs of catalyst deactivation were observed. Under basic conditions, the $\mathrm{Al}_{2} \mathrm{O}_{3}$ of the catalyst support can be transformed into $\mathrm{Al}(\mathrm{OH})_{3}$ (Eqs. 5 and 6) at the temperature and pressure used in this work [40].

$$
\begin{aligned}
& \mathrm{Al}_{2} \mathrm{O}_{3}+2 \mathrm{KOH} \rightarrow 2 \mathrm{KAlO}_{2}+\mathrm{H}_{2} \mathrm{O} \\
& \mathrm{KAlO}_{2}+\mathrm{CO}_{2}+3 \mathrm{H}_{2} \mathrm{O} \rightarrow 2 \mathrm{Al}(\mathrm{OH})_{3}+\mathrm{K}_{2} \mathrm{CO}_{3}
\end{aligned}
$$

A multivariate analysis by means of Spearman's test was carried out for the amounts of $\mathrm{Ni}, \mathrm{Al}$ and La leached from the catalysts, the loss (numerically calculated) for the $\mathrm{X}$ gly over time and the $\mathrm{pH}$ of the solution to elucidate whether or not the catalyst deactivation is related to the loss of part of the active phase of the catalyst. This test revealed statistically significant relationships between the percentage of La leached both with the $\mathrm{pH}$ of the solution ( $\mathrm{p}$-value $\left.=0.041 ; \mathrm{R}^{2}=0.82\right)$ and with the decay over time for the $\mathrm{X}$ gly $\left(p\right.$-value $\left.=0.045 ; R^{2}=0.82\right)$. These relationships suggest that the loss of active phase during reaction is one of the main reasons for catalyst deactivation in this work. 
The result of this test also indicates that the lower the $\mathrm{pH}$ of the solution, the greater is both the leaching of La from the catalyst to the liquid and the deactivation of the catalyst. This is consistent with results reported by other authors [41, 42] who have indicated that acidic conditions increase the solubility in water of various metals.

Ni nanoparticles supported on carbon nanofibres $(\mathrm{CNF})$ can be used in aqueous phase processes at elevated temperatures and pressures to control Ni oxidation and leaching. Haasterecht et al. [43] analysed the effect of the $\mathrm{pH}$ of the solution on the amount of $\mathrm{Ni}$ leached from the CNF catalysts during the APR of ethylene glycol. Ni leaching was found to be related to an increase in the Ni crystallite size. Concentrations of up to 7.1 ppm of leached nickel were observed, which represented the $0.28 \%$ of the total amount of nickel in the catalyst. This is in the same range and the amount of Ni leached in this work. With the addition of $\mathrm{KOH}(\mathrm{pH}=8-10)$ to the feed solutions leaching of $\mathrm{Ni}$ was inhibited, as the addition of $\mathrm{KOH}$ to the solutions helps to hinder Ni crystal growth. The modification of the catalyst with promotors is also a plausible option to decrease crystal growth, thus preventing the dissolution of the active metals of the catalysts in the solution. Pham et al. [44] demonstrated that the addition of small amounts of silica (5 wt.\%) helps improve the activity and stability of $\mathrm{Pd} /$ niobia catalysts. They concluded that addition of silica to niobia not only improved the stability of the support but also helped to retain smaller crystallite sizes for the Pd phase, resulting in improved catalytic performance.

To study the specific effect of the impurities as well as their possible interactions on the APR of glycerol, the results obtained during the first hour of each experiment have been 
statistically analysed and compared. The results of these analyses are summarised in Table 4 and Figure 4. The ANOVA analysis reveals that the presence of $\mathrm{CH}_{3} \mathrm{COOH}$, $\mathrm{CH}_{3} \mathrm{OH}$ and $\mathrm{KOH}$ in the 30 wt.\% glycerol solutions has a significant influence on the $\mathrm{X}$ gly, $\mathrm{CC}$ gas and $\mathrm{CC}$ liq obtained during the first hour of reaction. In contrast, these impurities do not exert any significant influence on the $\mathrm{CC}$ sol during the first hour and the $\mathrm{CC}$ sol is lower than $5 \%$ in all the experiments.

The independent terms (intercepts) in the models for the X gly, CC gas and CC liq provide the value of these variables in the centre of variation for the impurities considered (runs 9-11), which correspond to the results obtained with a $30 \mathrm{wt} . \%$ glycerol solution having 1.5 wt. $\%$ of $\mathrm{CH}_{3} \mathrm{COOH}, 2.5$ wt. $\%$ of $\mathrm{CH}_{3} \mathrm{OH}$ and 1.4 wt.\% of $\mathrm{KOH}$. The concentrations of these impurities in a $30 \mathrm{wt} . \%$ glycerol solution are very similar to the values obtained when the biodiesel-derived glycerol is neutralised with $\mathrm{CH}_{3} \mathrm{COOH}$ and refined with a vacuum distillation to recover $\mathrm{CH}_{3} \mathrm{OH}$ and $\mathrm{CH}_{3} \mathrm{COOH}$ $[3,28]$. Therefore, the comparison between these independent terms (or the results obtained in runs 9-11) with the results obtained in run 1 provides a direct comparison between the results obtained for a simulated refined glycerol and those for pure glycerol. The simulated refined glycerol provides lower X gly, CC gas and CC liq, which accounts for the results obtained by other authors [8] when comparing the APR of crude and reagent grade glycerol and, very importantly, highlights the significant influence of the biodiesel-derived impurities on the process. Specifically, in the presence of up to 5 wt. $\%$ of $\mathrm{CH}_{3} \mathrm{OH}, 3$ wt. $\%$ of $\mathrm{CH}_{3} \mathrm{COOH}$ and 2.8 wt. $\%$ of $\mathrm{KOH}$ during the first hour of reaction, the $\mathrm{X}$ gly, $\mathrm{CC}$ gas and CC liq vary by $61-92 \%, 14-31 \%$ and $45-70 \%$, respectively. 
The ANOVA analysis (positive or negative coefficients in the model) indicates that $\mathrm{CH}_{3} \mathrm{COOH}$ and $\mathrm{CH}_{3} \mathrm{OH}$ decrease the $\mathrm{X}$ gly, $\mathrm{CC}$ gas and $\mathrm{CC}$ liq. In contrast, the presence of $\mathrm{KOH}$ decreases the $\mathrm{X}$ gly and $\mathrm{CC}$ liq, but increases the $\mathrm{CC}$ gas. The Pareto analysis reveals that the impurities with the highest influence on these results are the $\mathrm{CH}_{3} \mathrm{OH}$ followed by both $\mathrm{CH}_{3} \mathrm{COOH}$ and $\mathrm{KOH}$. Furthermore, significant interactions between impurities are also detected and the analysis of the curvature for these variables shows a linear trend within the studied range with $95 \%$ confidence ( $p$-value $<0.05$ ). This indicates that with the experiments conducted the effect of the presence of the impurities can be evaluated from their absence in the glycerol solution to the upper limit considered for each impurity.

\subsubsection{Effect of one impurity}

Figure 4 shows the effect of each impurity as well as the binary and ternary mixtures on the $\mathrm{X}$ gly, $\mathrm{CC}$ gas and CC liq, making use of the interaction plots developed with the ANOVA analysis. The progressive addition of up to $5 \mathrm{wt} . \%$ of $\mathrm{CH}_{3} \mathrm{OH}$ to the glycerol solution decreases the $\mathrm{X}$ gly, $\mathrm{CC}$ gas and, very slightly, the $\mathrm{CC}$ liq. The effect of the addition of up to $3 \mathrm{wt} . \%$ of $\mathrm{CH}_{3} \mathrm{COOH}$ to the glycerol solution can be gathered comparing Figure 4 a with Figure $4 \mathrm{~b}$ (for the X gly), Figure $4 \mathrm{c}$ with Figure $4 \mathrm{~d}$ (for the $\mathrm{CC}$ gas) and Figure $4 \mathrm{e}$ with Figure $4 \mathrm{f}$ (for the CC liq). These comparisons show how the $\mathrm{CC}$ gas decreases with the addition of $\mathrm{CH}_{3} \mathrm{COOH}$ while the $\mathrm{X}$ gly and the $\mathrm{CC}$ liq are unaffected.

$\mathrm{CH}_{3} \mathrm{OH}$ and $\mathrm{CH}_{3} \mathrm{COOH}$ are products of the APR of glycerol, and their presence in the initial solution might modify the reaction pathways of the process, which could result in changes in the glycerol conversion and the product distribution in carbon basis (CC gas 
and CC liq). In addition, the presence of these two organic compounds diminishes the space-time in carbon basis $(\mathrm{W} / \mathrm{mC}$, mass of catalyst/mass flow rate of $\mathrm{C})$, which also accounts for the decreases in the glycerol conversion and changes in the product distribution. Boga et al. [8] reported that the addition of $\mathrm{CH}_{3} \mathrm{OH}$ to a glycerol solution in a similar $\mathrm{CH}_{3} \mathrm{OH} /$ organics ratio $(0.17 \mathrm{~g} / \mathrm{g})$ as that used in this work $(0.14 \mathrm{~g} / \mathrm{g})$ exerted a negligible effect on the glycerol conversion during the APR of glycerol in a semibatch reactor at $225^{\circ} \mathrm{C}$ and 29 bar. This discrepancy could be the consequence of having used a higher space-time ( $37 \mathrm{~g}$ catalyst $\mathrm{min} / \mathrm{g}$ glycerol) than that used in this work (25 g catalyst min/g glycerol). However, Boga et al. reported a $\mathrm{CH}_{3} \mathrm{OH}$ conversion of $66 \%$, which explains the decrease in the $\mathrm{CC}$ gas observed in the present work. Furthermore, the ratio between glycerol and methanol converted was found to vary with the catalyst used and with the composition of the crude glycerol, which explains the depletion in the glycerol conversion observed in our work. Vasiliadou et al. [45] studied the APR of glycerol in a batch reactor at $220-250{ }^{\circ} \mathrm{C}$ and 35 bar $\mathrm{N}_{2}$ initial pressure with a Pt-SiO 2 catalyst using $\mathrm{CH}_{3} \mathrm{OH}$ as a hydrogen donor. They demonstrated that $70 \%$ of the total $\mathrm{H}_{2}$ was produced from the reforming of $\mathrm{CH}_{3} \mathrm{OH}$. Therefore, these two works indicate that the reactivity of $\mathrm{CH}_{3} \mathrm{OH}$ under APR conditions depends on the catalyst and the composition of the crude glycerol.

In addition, it should be borne in mind that in this work the CC liq includes both $\mathrm{CH}_{3} \mathrm{OH}$ and $\mathrm{CH}_{3} \mathrm{COOH}$, since they are also glycerol APR liquid products. This accounts for the small and negligible variations observed in the $\mathrm{CC}$ liq with the addition of $\mathrm{CH}_{3} \mathrm{OH}$ and $\mathrm{CH}_{3} \mathrm{COOH}$ to the glycerol solution, respectively, probably due to the compensatory effect of two developments: their production from glycerol APR 
reactions and their elimination during reaction due to their initial presence in the solution.

The chemical analysis of the liquid phase revealed a negligible concentration of acetic acid in the liquid for all experiments; with indicates both a small $\mathrm{CH}_{3} \mathrm{COOH}$ production from glycerol and that $100 \%$ of the $\mathrm{CH}_{3} \mathrm{COOH}$ fed with the glycerol solution /produced from glycerol was converted into gases and/or other liquid products. Conversely, in the case of $\mathrm{CH}_{3} \mathrm{OH}$, the concentration of this compound in the liquid for runs $1-4$ is as follows: $0.31,0.26,2.05$ and 1.58 wt. $\%$. Therefore, the conversion of $\mathrm{CH}_{3} \mathrm{OH}$ in run 3 , having regard to the fact that the $\mathrm{CH}_{3} \mathrm{OH}$ produced from glycerol (run 1), is around $53 \%$, which confirms the relatively low reactivity of this impurity under the operating conditions tested in this work.

As regards the presence of $\mathrm{KOH}$ in the glycerol solution, up to $2.8 \mathrm{wt} . \%$ of $\mathrm{KOH}$ could be added to the solution without exerting any statistically significant influence on either the X gly or the CC liq, but slightly increasing the CC gas. King et al [4] also reported an increase in gas production with the addition of $0.1 \mathrm{wt} . \%$ of $\mathrm{KOH}$ to a $10 \mathrm{wt} . \%$ glycerol solution (until a $\mathrm{pH}$ of 12 was reached) during the aqueous phase reforming of this mixture at $225^{\circ} \mathrm{C}$ and 30 bar. Gas formation occurs via $\mathrm{C}-\mathrm{C}$ scission, which takes place via a base-catalysed pathway and is facilitated at high $\mathrm{pH}[4,46]$.

\subsubsection{Effect of two impurities}

In relation to the binary combinations $\left(\mathrm{KOH}-\mathrm{CH}_{3} \mathrm{OH}, \mathrm{KOH}-\mathrm{CH}_{3} \mathrm{COOH}\right.$ and $\mathrm{CH}_{3} \mathrm{OH}-$ $\mathrm{CH}_{3} \mathrm{COOH}$ ), it is worth mentioning that the effect of the presence of $\mathrm{KOH}$ is different when it is alone or when accompanied by $\mathrm{CH}_{3} \mathrm{OH}$ or $\mathrm{CH}_{3} \mathrm{COOH}$ due to the existence of 
significant interactions between the impurities. The addition of $\mathrm{CH}_{3} \mathrm{OH}$ or $\mathrm{CH}_{3} \mathrm{COOH}$ to a glycerol solution containing $\mathrm{KOH}$ decreases the $\mathrm{X}$ gly, $\mathrm{CC}$ gas and $\mathrm{CC}$ liq, as can be seen from Figures $4 \mathrm{a}$, c and e for the addition of $\mathrm{CH}_{3} \mathrm{OH}$ and comparing these with Figures $4 \mathrm{~b}$, $\mathrm{d}$ and $\mathrm{f}$ in the case of adding $\mathrm{CH}_{3} \mathrm{COOH}$. These results can be explained by the progressive removal of $\mathrm{KOH}$ and its transformation into $\mathrm{CH}_{3} \mathrm{OK}$ (Eq. 7) [47] or $\mathrm{CH}_{3} \mathrm{COOK}$ (Eq. 8), creating a $\mathrm{CH}_{3} \mathrm{COOH} / \mathrm{CH}_{3} \mathrm{COO}^{-}$buffer solution for the latter, and thus decreasing the effect that $\mathrm{KOH}$ exerts on the process in both cases. The occurrence of these reactions was also observed in a previous work reporting the effect of these impurities during the steam reforming of glycerol [26].

$$
\begin{aligned}
& \mathrm{CH}_{3} \mathrm{OH}+\mathrm{KOH} \rightarrow \mathrm{CH}_{3} \mathrm{OK}+\mathrm{H}_{2} \mathrm{O} \\
& \mathrm{CH}_{3} \mathrm{COOH}+\mathrm{KOH} \rightarrow \mathrm{CH}_{3} \mathrm{COOK}+\mathrm{H}_{2} \mathrm{O}
\end{aligned}
$$

King et al. [4] reported the positive effect that the addition of $\mathrm{KOH}$ to a glycerol solution exerts on the APR process using a Pt-based catalyst. They proposed that $\mathrm{K}$ could ascribe the increase in activity with the addition of $\mathrm{KOH}$ to the modification of active metal phase in the catalyst. The promotional effect of the addition of $\mathrm{K}^{+}$makes the active metal phase of the catalyst more electron-deficient. However, as $\mathrm{KOH}$ was added to the solution and both $\mathrm{K}^{+}$and $\mathrm{OH}^{-}$can interact with the surface of the catalyst, they were unable to distinguish between the $\mathrm{K}^{+}$and/or $\mathrm{OH}^{-}$promotional effects. Conversely, the strategy used in this work to evaluate the influence of the different individual, binary and ternary mixtures helps to gain a better insight into the relative influence of $\mathrm{H}^{+}, \mathrm{OH}^{-}$and $\mathrm{K}^{+}$on the process. 
The results of this work suggest that the decreases observed in X gly, CC gas and CC liq when adding $\mathrm{CH}_{3} \mathrm{OH}$ or $\mathrm{CH}_{3} \mathrm{COOH}$ to a solution containing glycerol and $\mathrm{KOH}$ might be the consequence of the increases in the $\mathrm{K}^{+} / \mathrm{OH}^{-}$and $\mathrm{K}^{+} / \mathrm{H}^{+}$ratios of the solutions, respectively. No significant differences were found between the results obtained with only $\mathrm{CH}_{3} \mathrm{OH}$ or with the binary mixture $\mathrm{CH}_{3} \mathrm{OH}+\mathrm{KOH}$, probably due to the transformation of $\mathrm{CH}_{3} \mathrm{OH}$ into $\mathrm{CH}_{3} \mathrm{OK}$ as described by Eq. 7. This suggests that in the presence of $\mathrm{CH}_{3} \mathrm{OH}$, the addition of $\mathrm{K}^{+}$to the solution does not exert a positive catalytic influence on the process and thus the same results are obtained with the presence of either $\mathrm{CH}_{3} \mathrm{OH}$ or $\mathrm{CH}_{3} \mathrm{OK}$ in the glycerol solution. Therefore, the increase observed in the $\mathrm{CC}$ gas with the addition of $\mathrm{KOH}$ is believed to have been caused by the presence of $\mathrm{OH}^{-}$in the glycerol solution rather than by $\mathrm{K}^{+}$. This accounts for higher $\mathrm{C}-\mathrm{C}$ scissions producing gases which occur via a base-catalysed pathway facilitated by a high $\mathrm{OH}^{-}$concentration in the reaction medium $[4,46]$.

Interestingly, the addition of $\mathrm{CH}_{3} \mathrm{COOH}$ to the glycerol solution does not change the $\mathrm{X}$ gly obtained with pure glycerol (as describe above) in spite of the increase in the $\mathrm{C}$ content of the feed which decreases the space-time in carbon basis (g catalyst $\mathrm{min} / \mathrm{g}$ carbon). The space-time decreases from $64 \mathrm{~g}$ catalyst $\mathrm{min} / \mathrm{g} \mathrm{C}$ for pure glycerol to 58 and $55 \mathrm{~g}$ catalyst $\mathrm{min} / \mathrm{g} \mathrm{C}$ with the addition of $\mathrm{CH}_{3} \mathrm{COOH}$ and $\mathrm{CH}_{3} \mathrm{OH}$, respectively. These decreases in the space-time are very similar (10 and 13\%, respectively). However, a sharp decay in the glycerol conversion with the addition of $\mathrm{CH}_{3} \mathrm{OH}$ is, observed, which suggests that the presence of $\mathrm{H}^{+}$in the solution can compensate for the decrease in space velocity. This indicates that $\mathrm{H}^{+}$might have a positive catalytic effect on the process as it favours acid-catalysed dehydrations in hot compressed water [48, 49], which increases the CC liq and X gly. Conversely, the $\mathrm{CC}$ gas decreases as the 
reaction media becomes more acidic, suggesting that gas formation is not favoured under acid conditions, as reported by Davda et al. [48]. Therefore, the progressive addition of $\mathrm{KOH}$ to a solution containing glycerol and $\mathrm{CH}_{3} \mathrm{COOH}$ decreases the $\mathrm{X}$ gly and $\mathrm{CC}$ liq and increases the $\mathrm{CC}$ gas due to the increase in the $\mathrm{K}^{+} / \mathrm{H}^{+}$ratio and the decrease in the $\mathrm{K}^{+} / \mathrm{OH}^{-}$ratio of the solution occurring when the $\mathrm{CH}_{3} \mathrm{COOH}$ is progressively transformed into $\mathrm{CH}_{3} \mathrm{COOK}$. In addition, the addition of $\mathrm{KOH}$ to the glycerol/ $\mathrm{CH}_{3} \mathrm{COOH}$ solution decreases its acidity thus allowing $\mathrm{OH}^{-}$catalysis for $\mathrm{H}_{2}$ production rather than $\mathrm{H}^{+}$catalysis that leads to dehydration.

As regards the $\mathrm{CH}_{3} \mathrm{OH}-\mathrm{CH}_{3} \mathrm{COOH}$ mixture, Figures $4 \mathrm{~b}$, $\mathrm{d}$ and $\mathrm{f}$ show how the progressive addition of $\mathrm{CH}_{3} \mathrm{OH}$ to a glycerol solution containing 3 wt. $\% \mathrm{CH}_{3} \mathrm{COOH}$ does not modify the X gly, CC gas or CC liq. The presence of these two impurities can lead to the formation of $\mathrm{CH}_{3} \mathrm{COOCH}_{3}$ by esterification (Eq. 9) [26], but the $\mathrm{pH}$ of the solution is not greatly modified as it shifts from 2.46 to 2.53 with the addition of $\mathrm{CH}_{3} \mathrm{OH}$.

$$
\mathrm{CH}_{3} \mathrm{COOH}+\mathrm{CH}_{3} \mathrm{OH} \rightarrow \mathrm{CH}_{3} \mathrm{COOCH}_{3}+\mathrm{H}_{2} \mathrm{O}
$$

Very interestingly, the comparison between Figures $4 \mathrm{a}$ with $\mathrm{b}$ and $4 \mathrm{e}$ with f reveals that the addition of $3 \mathrm{wt} . \% \mathrm{CH}_{3} \mathrm{COOH}$ to a solution containing 5 wt. $\%$ of $\mathrm{CH}_{3} \mathrm{OH}$ slightly increases the $\mathrm{X}$ gly and $\mathrm{CC}$ liq due to the increase in the $\mathrm{pH}$ of the solution, providing evidence of the positive effect that $\mathrm{H}^{+}$ions have on the process. This addition exerts a negligible effect on the $\mathrm{CC}$ gas, suggesting that $\mathrm{H}^{+}$exerts a positive effect on glycerol conversion into liquid products. This is due to a greater spread of the dehydration reactions which produce intermediate liquid products [48, 49]. 


\subsubsection{Effect of the three impurities}

When all three impurities are present in the glycerol solution, different reactions (Eqs. 7-11) can take place depending on their concentrations [26]. Most of these reactions might take place during the preparation of the solutions. In addition, some of them can occur when the solutions are fed to the reactor, either before reaching the reactor or in the bottom part of the reactor, prior to reach the catalytic bed.

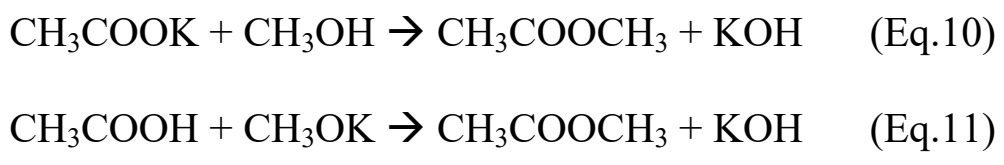

Figures $4 \mathrm{~b}, \mathrm{~d}$ and $\mathrm{f}$ show the effect of the presence of the three impurities on the $\mathrm{X}$ gly, CC gas and CC liq, respectively. These figures show how the progressive addition of $\mathrm{CH}_{3} \mathrm{OH}$ to a glycerol solution containing $\mathrm{CH}_{3} \mathrm{COOH}$ and $\mathrm{KOH}$ slightly decreases the CC gas (from 21 to $18 \%$ ) without exerting any significant effect on either the $\mathrm{X}$ gly or the $\mathrm{CC}$ liq. The addition of $\mathrm{CH}_{3} \mathrm{OH}$ to this binary mixture leads to the formation of $\mathrm{CH}_{3} \mathrm{OK}$ [26], thus increasing the $\mathrm{K}^{+} / \mathrm{OH}^{-}$ratio which accounts for the decrease observed in the $\mathrm{CC}$ gas. Furthermore, the progressive addition of $\mathrm{KOH}$ to a glycerol solution containing $\mathrm{CH}_{3} \mathrm{COOH}$ and $\mathrm{CH}_{3} \mathrm{OH}$ decreases the $\mathrm{X}$ gly. In this case the addition of $\mathrm{KOH}$ to the solution leads to the formation of $\mathrm{CH}_{3} \mathrm{COOK}$ and $\mathrm{CH}_{3} \mathrm{OK}$, which increases the $\mathrm{K}^{+} / \mathrm{OH}^{-}$ratio.

The comparison between Figures $4 \mathrm{a}$ with $\mathrm{b}$, $\mathrm{c}$ with $\mathrm{d}$ and e with $\mathrm{f}$ reveals that when the glycerol solution contains the highest amount of the three impurities, lower amounts of $\mathrm{X}$ gly, $\mathrm{CC}$ gas and CC liq are achieved in comparison to those obtained with pure 
glycerol. This is in good agreement with other works comparing the results obtained with pure and crude glycerol [8].

\subsection{Gas composition}

Figure 5 shows the gas composition obtained for the different experiments. The impurities have a statistically significant influence on the relative amount of $\mathrm{H}_{2}, \mathrm{CO}_{2}$, $\mathrm{CO}$ and $\mathrm{CH}_{4}$ (p-values $\left.<0.05\right)$ which varied as follows: $22-48 \%, 36-51 \%, 1-7 \%$ and $13-$ $22 \%$, respectively.

Studying the evolution of the gas over time, the general tendency shows small variations for the proportions of $\mathrm{H}_{2}, \mathrm{CO}_{2}$ and $\mathrm{CH}_{4}$. Slight increases were detected for $\mathrm{CO}$ although the relative amount of this gas is quite low. This indicates that catalyst deactivation does not greatly affect gas selectivity, i.e. lower amounts of all the gases are produced but without modifying the composition of the gas. One exception is run 5, which contains $\mathrm{KOH}$ as the only impurity. In this case there were increases in the proportions of $\mathrm{H}_{2}$ and $\mathrm{CO}_{2}$ along with decreases in the concentrations of $\mathrm{CO}$ and $\mathrm{CH}_{4}$. This suggests that the presence of $\mathrm{KOH}$ in the solution potentiates methane reforming $\left(\mathrm{CH}_{4}+2 \mathrm{H}_{2} \mathrm{O} \Leftrightarrow \mathrm{CO}_{2}+4 \mathrm{H}_{2}\right)$ and the WGS $\left(\mathrm{CO}+\mathrm{H}_{2} \mathrm{O} \Leftrightarrow \mathrm{CO}_{2}+\mathrm{H}_{2}\right)$ reactions. Borowiecki et al. [50] and Nagaraja et al. [51] concluded that the modification of Nibased catalysts with $\mathrm{K}$ increases the activity of the catalyst. This catalyst modification with $\mathrm{K}$ can occur in situ during the reaction, as reported by King et al. [4] who found that the $\mathrm{K}^{+}$ions present in the glycerol solution can interact with the active metal phase of the catalyst under APR conditions. This interaction could increase with the reaction time, as the contact time between the catalyst and $\mathrm{K}^{+}$ions increases. This accounts for the change in the gas selectivity over time observed in this work. To gain a better 
insight into the effect of the modification of the catalyst with $\mathrm{K}$, some of the used catalyst were characterised by ICP. The amount of K deposited on the catalyst for runs 5 and 9-11 was $10.48 \pm 0.14 \mathrm{mg} \mathrm{K} / \mathrm{g}$ catalyst $\mathrm{g} \mathrm{K}$ fed and $4.46 \pm 0.48 \mathrm{mg} \mathrm{K} / \mathrm{g}$ catalyst $\mathrm{g} \mathrm{K}$ fed, respectively. This corresponds to $\mathrm{K}$ depositions of $7.86 \pm 0.11 \%$ and $3.50 \pm 0.36 \%$ respectively, with respect to the total amount of $\mathrm{K}$ fed during the $3 \mathrm{~h}$ of experiment. This indicates that $\mathrm{K}$ deposition depends on the $\mathrm{pH}$ of the solution and higher the $\mathrm{pH}$, the greater are both the deposition of $\mathrm{K}$ on the catalyst and the increase in its catalytic activity.

Table 5 lists the relative influence of the impurities on the gas composition (Pareto analysis) as well as their positive or negative effect (terms in the codec model). The ANOVA analysis reveals that the impurities exert a significant influence on the concentration of $\mathrm{H}_{2}, \mathrm{CO}$ and $\mathrm{CO}_{2}$ in the gas during the first hour of experiment. The analysis of the curvature for these variables shows a linear trend within the studied range with $95 \%$ confidence ( $p$-value $<0.05$ ). Figure 6 plots the effects of each impurity as well as the binary and ternary mixtures on the proportions of $\mathrm{H}_{2}, \mathrm{CO}_{2}$ and $\mathrm{CO}$ in the gas, obtained with the ANOVA analysis. The concentrations of these gases range from 23 to 43 vol. $\%$, from 36 to 51 vol.\% and from 0.4 to 5 vol.\%, respectively. Conversely, the relative amount of $\mathrm{CH}_{4}$ during the first hour is around 17 vol.\% regardless of the presence of the impurities considered. The comparison between the gas compositions obtained for run 1 and the intercepts of Table 5 (or runs 9-11) reveals a higher proportion of $\mathrm{H}_{2}$ and lower proportions of $\mathrm{CO}$ and $\mathrm{CO}_{2}$ in the gas when feeding simulated crude glycerol than when using pure glycerol. 
$\mathrm{KOH}$ has the greatest influence on the composition of the gas, followed by $\mathrm{CH}_{3} \mathrm{OH}$ and $\mathrm{CH}_{3} \mathrm{COOH}$, both with a similar influence. The coefficients of the models indicate that the addition of $\mathrm{KOH}$ to the glycerol solution considerably increases the relative amount of $\mathrm{H}_{2}$ and decreases the proportions of $\mathrm{CO}$ and $\mathrm{CO}_{2}$ in the gas. The addition of $\mathrm{CH}_{3} \mathrm{COOH}$ to the solution slightly decreases the proportion of $\mathrm{H}_{2}$ and increases the proportions of $\mathrm{CO}_{2}$ and $\mathrm{CO}$, while $\mathrm{CH}_{3} \mathrm{OH}$ slightly increases the proportions of $\mathrm{H}_{2}$ and $\mathrm{CO}$ and decreases the relative amount of $\mathrm{CO}_{2}$ in the gas. However, significant interactions between the impurities were detected which means that the effect of each impurity is dependent on the others.

\subsubsection{Effect of one impurity}

Figure 6 shows how the addition of up to 5 wt. $\%$ of $\mathrm{CH}_{3} \mathrm{OH}$ alone to the glycerol solution increases the proportion of $\mathrm{H}_{2}$ in the gas very slightly, while the addition of $\mathrm{CH}_{3} \mathrm{COOH}$ leads to a small increase in the proportion of $\mathrm{CO}_{2}$. However, as predicted by the Pareto analysis, the effect of the presence of either of these two impurities alone on the composition of the gas is very weak and the variations observed can be within the experimental uncertainty. Conversely, the addition of $\mathrm{KOH}$ to the solution exerts a great impact on the composition of the gas. The proportion of $\mathrm{H}_{2}$ increases sharply and the relative amounts of $\mathrm{CO}$ and $\mathrm{CO}_{2}$ decrease severely. Gas formation occurs via $\mathrm{C}-\mathrm{C}$ scission, which occurs via a base-catalysed pathway facilitated at high $\mathrm{pH}[4,46]$. Therefore, this increase in the proportion of $\mathrm{H}_{2}$ in the gas could be the consequence of the increase in gas production, which causes a reduction in the production of intermediate liquids. This decreases the $\mathrm{H}_{2}$ consumption in the hydrogenation reactions,

which accounts for the increase observed in the relative amount of $\mathrm{H}_{2}$ in the gas. King et al. [4] also reported an increase in the $\mathrm{H}_{2}$ selectivity with the addition of $\mathrm{KOH}$ to a 
glycerol solution using a Pt-Re/C catalyst. They concluded that this development was the consequence of lower $\mathrm{H}_{2}$ consumption in the hydrogenation reactions, as $\mathrm{KOH}$ disfavours dehydration reactions and C-O scissions.

\subsubsection{Effect of two impurities}

In relation to the binary combinations it is worth mentioning that the effect of the presence of $\mathrm{KOH}$ is different when it is alone or accompanied by $\mathrm{CH}_{3} \mathrm{COOH}$ than when it is accompanied by $\mathrm{CH}_{3} \mathrm{OH}$. Figures $6 \mathrm{a}$, $\mathrm{c}$ and e show how the progressive addition of $\mathrm{CH}_{3} \mathrm{OH}$ to a glycerol solution containing $\mathrm{KOH}$ does not greatly modify the effect of the presence of $\mathrm{KOH}$ alone, probably because the $\mathrm{pH}$ of the solution is not greatly modified (it varies from 13.29 to 13.40 ). The proportions of $\mathrm{H}_{2}$ and $\mathrm{CO}$ in the gas remain invariable, while a small increase in the proportion of $\mathrm{CO}_{2}$ occurs. Conversely, the addition of $\mathrm{CH}_{3} \mathrm{COOH}$ to a glycerol solution containing $\mathrm{KOH}$ significantly changes the composition of the gas. Specifically, the comparisons between Figures 6 a with b, c with $\mathrm{d}$ and e with $\mathrm{f}$ show how this addition causes a reduction in the proportion of $\mathrm{H}_{2}$ and an increase in the proportion of $\mathrm{CO}_{2}$, while the relative amount of $\mathrm{CO}$ in the gas remains unaffected. The progressive addition of up to $3 \mathrm{wt} . \%$ of $\mathrm{CH}_{3} \mathrm{COOH}$ to a glycerol solution having $2.8 \mathrm{wt} . \%$ of $\mathrm{KOH}$ decreases the $\mathrm{pH}$ of the solution from 13.29 to 11.84 , which decreases the concentration of $\mathrm{OH}^{-}$in the solution and thus diminishes the production of $\mathrm{H}_{2}$ [4].

As regards the combination of the two organic impurities $\left(\mathrm{CH}_{3} \mathrm{OH}-\mathrm{CH}_{3} \mathrm{COOH}\right)$, Figures $6 \mathrm{~b}, \mathrm{~d}$ and $\mathrm{f}$ show how the progressive addition of $\mathrm{CH}_{3} \mathrm{OH}$ to a glycerol solution containing the highest amount of $\mathrm{CH}_{3} \mathrm{COOH}$ considered in this work slightly increases the proportion of $\mathrm{H}_{2}$ and decreases the proportion of $\mathrm{CO}_{2}$ to the same levels as those 
achieved with the presence of $\mathrm{CH}_{3} \mathrm{OH}$ alone. Very similar developments occur in the proportions of $\mathrm{H}_{2}$ and $\mathrm{CO}$ with the addition of $\mathrm{CH}_{3} \mathrm{OH}$ alone as when it is added in the presence of the highest amount of $\mathrm{CH}_{3} \mathrm{COOH}$. $\mathrm{CH}_{3} \mathrm{OH}$ is a final liquid product in the APR of glycerol and can be transformed into $\mathrm{H}_{2}$ by reforming in the final steps of the process. It is therefore hardly affected by the presence of $\mathrm{CH}_{3} \mathrm{COOH}$ in the glycerol solution.

\subsubsection{Effect of three impurities}

Figures $6 \mathrm{~b}$, $\mathrm{d}$ and $\mathrm{f}$ show the effect of the presence of the three impurities on the proportions of $\mathrm{H}_{2}, \mathrm{CO}_{2}$ and $\mathrm{CO}$ in the gas, respectively. It is observed how the proportion of $\mathrm{H}_{2}$ in the gas increases, while the relative amounts of $\mathrm{CO}$ and $\mathrm{CO}_{2}$ in the gas decrease in comparison with the results obtained with pure glycerol. The addition of a third impurity to the different binary mixtures has different consequences for the composition of the gas. Specifically, up to $5 \mathrm{wt} . \%$ of $\mathrm{CH}_{3} \mathrm{OH}$ can be added to a glycerol solution containing $\mathrm{CH}_{3} \mathrm{COOH}$ and $\mathrm{KOH}$ without modifying the gas composition of the binary mixture. Conversely, the addition of $\mathrm{CH}_{3} \mathrm{COOH}$ to the binary mixture $\mathrm{CH}_{3} \mathrm{OH}-$ $\mathrm{KOH}$ decreases the proportion of $\mathrm{H}_{2}$ in the gas. This depletion is the consequence of the progressive neutralisation of $\mathrm{KOH}$ with the addition of $\mathrm{CH}_{3} \mathrm{COOH}$ which decreases the $\mathrm{pH}$ of the solution, thus decreasing the relative amount of $\mathrm{H}_{2}$ in the gas [4].

The gas composition obtained with the binary organic mixture $\mathrm{CH}_{3} \mathrm{OH}-\mathrm{CH}_{3} \mathrm{COOH}$ is modified with the addition of $\mathrm{KOH}$ to the solution: an increase in the proportion of $\mathrm{H}_{2}$ together with a drop in the relative amount of $\mathrm{CO}$ in the gas takes place. The addition of $\mathrm{KOH}$ increases the $\mathrm{pH}$ of the solution due to the increase in the concentration of $\mathrm{OH}^{-}[4$, 
46]. In addition, $\mathrm{K}^{+}$exerts a positive catalytic effect on gas production and the water gas shift reaction [36, 37].

\subsection{Liquid composition}

Figure 7 summarises the relative amount of the different families of compounds present in the liquid for the experiments. The liquid phase is made up of a mixture of alcohols, aldehydes, ketones, and esters together with unreacted glycerol and water. The alcohols include monohydric alcohols (majorly methanol and ethanol and in lower proportion 2butanol, 2-pentanol and 3-pentanol), polyhydric alcohols (propane-1,2-diol, ethane-1,2diol and butane-2,3-diol) and, in lower proportions, monohydric substituted and alicyclic alcohols. The ketones include C3-ketones such as propan-2-one (acetone) and 1-hydroxy-propan-2-one and C4-ketones such as 3-hydroxy-butan-2-one. Acetaldehyde is the most abundant compound for the aldehydes. The presence of these compounds in the condensates is consistent with the pathway proposed in Figure 2 and those proposed by several authors who have studied the APR of glycerol [4, 5, 19, 32-35]. Acetic acid methyl ester and 1,2-propanediol-2 acetate are the most abundant ester compounds, which suggest that esterification reactions can also take place with the presence of some impurities.

Increases and decreases in the proportions of these families with time are detected. Monohydric alcohols and C3-ketones show the greatest variations in composition over time. Specifically, decreases over time occur for the proportions of monohydric alcohols in the vast majority of the experiments while C3-ketones show increases over time for some of them. Many of the decreases observed in the proportions of the former take place along with increases in the proportions of the latter. The multivariate Spearman's 
test detected a significant relationship ( $\mathrm{p}$-value $<0.05)$ between the increases and decreases of these two families of compounds with time. In contrast, the proportions of aldehydes, polyhydric alcohols, C4-ketones and esters remain relatively steady over time for the vast majority of the experiments.

The statistical analysis of the results (Table 6) indicates that the impurities exert a significant influence during the first hour of reaction on the proportions of monohydric alcohols, polyhydric alcohols, aldehydes and C3-ketones, the proportion of esters being unaffected. The presence of $\mathrm{CH}_{3} \mathrm{COOH}$ and $\mathrm{CH}_{3} \mathrm{OH}$ exerts the highest influence on the proportions of monohydric and polyhydric alcohols, while $\mathrm{KOH}$ has a great influence on the relative amounts of aldehydes and C3-ketones. The relative amount of the liquid compounds shows a linear trend within the studied range of the concentration of impurities with $95 \%$ confidence ( $p$-value $<0.05$ ). Figure 8 shows the effect of the individual presence of $\mathrm{CH}_{3} \mathrm{OH}, \mathrm{CH}_{3} \mathrm{COOH}$ and $\mathrm{KOH}$ together with the different binary and ternary mixtures of these compounds on the relative amounts of monohydric and polyhydric alcohols, aldehydes and C3-ketones.

\subsubsection{Effect of one impurity}

The addition of up to $5 \mathrm{wt} . \%$ of $\mathrm{CH}_{3} \mathrm{OH}$ to the glycerol solution does not exert any significant influence on the proportions of these families of compounds. However, it was found that the addition of $\mathrm{CH}_{3} \mathrm{OH}$ as a impurity to the glycerol solution increases the proportion of $\mathrm{CH}_{3} \mathrm{OH}$ from 1 to $12 \%$ and decreases the relative amounts of ethanol (from 16 to $10 \%$ ) and 2-butanol (from 4 to $0 \%$ ) in the liquid product. This does not significantly modify the proportion of monohydric alcohols in the liquid. It is believed 
that the increase in the proportion of $\mathrm{CH}_{3} \mathrm{OH}$ in the liquid is a direct consequence of its presence in the initial glycerol solution, as the liquid phases for runs 3, 7 and 8 have the highest proportions of this compound (around 12.5\%). Furthermore, the APR of runs 911 , having half the initial concentration of $\mathrm{CH}_{3} \mathrm{OH}$ in the glycerol solution than that used for runs 3, 4, 7 and 8 , gives a liquid product with half the relative amount of $\mathrm{CH}_{3} \mathrm{OH}(6.6 \%)$. These developments together with the low $\mathrm{CH}_{3} \mathrm{OH}$ conversions (section 3.1.1) confirm the low reactivity of this impurity under the operating conditions tested in this work.

The addition of $\mathrm{CH}_{3} \mathrm{COOH}$ to the glycerol solution causes a significant decrease in the proportions of monohydric alcohols (both methanol and ethanol, the most abundant) and an increase in the relative amount of 1-hydroxypropan-2-one, without modifying the proportion of acetone in the liquid. This variation accounts for an increase in glycerol dehydration reactions, which suggests that route A prevails over route $\mathrm{C}$ under acidic conditions. Several authors have reported that acidic conditions cause more widespread dehydration reactions [4, 34, 52-54]. In addition, under acidic conditions, the 2,3-dihydroxypropanal (glyceraldehyde) dehydration/hydrogenation route to propane-1,2-diol prevails over the decarbonylation to ethane-1,2-diol [4], which accounts for the decrease observed in the proportions of methanol and ethanol (mostly produced in the final steps of route $\mathrm{C}$ ), and the increase observed in the proportions of liquid products obtained from route A.

The presence of up to $2.8 \mathrm{wt} . \%$ of $\mathrm{KOH}$ alone in the glycerol solution does not significantly influence the composition of the liquid phase. As an exception, the 
proportion of aldehydes in the liquid decreases, suggesting that either acetaldehyde decomposition is favoured or its formation is hindered under an alkali $\mathrm{pH}$.

\subsubsection{Effect of two impurities}

The progressive addition of $\mathrm{KOH}$ to a glycerol solution containing either $\mathrm{CH}_{3} \mathrm{OH}$ or $\mathrm{CH}_{3} \mathrm{COOH}$ changes the effect that these two organic impurities exert alone. When $\mathrm{KOH}$ is added to a glycerol solution containing $\mathrm{CH}_{3} \mathrm{OH}$ (Figures $8 \mathrm{a}$, c, e and $\mathrm{g}$ ), the proportion of polyhydric alcohols increases due to the increase in the relative amount of butane-2,3-diol, while the relative amount of aldehydes decreases. $\mathrm{CH}_{3} \mathrm{OK}$, which has a mid nucleophilic character, can be formed in the presence of these two impurities (Eq. 7) [26], and can promote the formation of alcohols with a higher number of carbon atoms via Cannizzaro type reactions [5, 33-35]. The decrease in the proportion of aldehydes might have been caused by the positive effect that $\mathrm{KOH}$ exerts on its decomposition and/or because basic conditions hinder its formation, as explained above. Conversely, statistically significant variations for the other families of compounds are not observed.

The addition of $\mathrm{KOH}$ to a glycerol solution containing $\mathrm{CH}_{3} \mathrm{COOH}$ (Figures $8 \mathrm{~b}$, d, f and h) produces a decrease in the proportion of C3-ketones in the liquid, while the relative amounts of monohydric and polyhydric alcohols and aldehydes are unaffected. The chemical analysis of the liquid reveals that the depletion observed in the proportion of C3-ketones accounts for a decrease in the relative amount of 1-hydroxy propan-2-one. Acidic conditions cause more widespread dehydration reactions $[4,34,52-54]$ thus promoting dehydration/hydrogenation routes [4]. Route A thus prevails over route C. 
However, the $\mathrm{pH}$ of the solution increases with the addition of $\mathrm{KOH}$, shifting the reactions in the liquid phase towards route $\mathrm{C}$.

As regards the binary mixture of the two organic impurities, it was found that the addition of $\mathrm{CH}_{3} \mathrm{OH}$ to a glycerol solution containing $\mathrm{CH}_{3} \mathrm{COOH}$ increases the relative amount of monohydric alcohols and decreases the polyhydric alcohols. The proportions of aldehydes and C3-ketones are unaffected. The increase in the concentration of monohydric alcohols is the consequence of the initial presence of $\mathrm{CH}_{3} \mathrm{OH}$ in the glycerol solution, since this organic compound is not very reactive under the operating conditions considered in this work. Very interestingly, there are no significant differences between the compositions of the liquid phase obtained with the presence of $\mathrm{CH}_{3} \mathrm{OH}$ alone in the glycerol solution and with the binary mixture $\mathrm{CH}_{3} \mathrm{OH}-\mathrm{CH}_{3} \mathrm{COOH}$. This suggests that $\mathrm{CH}_{3} \mathrm{OH}$ is responsible for the change in the composition of the liquid phase observed in the presence of these two impurities.

\subsubsection{Effect of three impurities}

The addition of a third impurity to the different binary mixtures has different consequences for the composition of the liquid phase. Figures $8 \mathrm{~b}, \mathrm{~d}$, f and h show the effects of the addition of $\mathrm{KOH}$ to the binary mixture $\mathrm{CH}_{3} \mathrm{COOH}-\mathrm{CH}_{3} \mathrm{OH}$ and the addition of $\mathrm{CH}_{3} \mathrm{OH}$ to the binary mixture $\mathrm{CH}_{3} \mathrm{COOH}-\mathrm{KOH}$.

The addition of $\mathrm{KOH}$ to a glycerol solution containing 3 wt. $\%$ of $\mathrm{CH}_{3} \mathrm{COOH}$ and 5 wt. $\%$ of $\mathrm{CH}_{3} \mathrm{OH}$ increases the proportion of polyhydric alcohols and decreases the relative amounts of aldehydes and C3-ketones in the liquid. However, this addition does not significantly modify the proportion of monohydric alcohols. The variations in the proportions of polyhydric alcohols and C3-ketones account for the increase in the 
proportion of propane-1,2-diol and the decrease in the relative amount of 1hydroxypropan-2-one, respectively; while acetaldehyde is responsible for the decrease observed in the proportion of aldehydes. These variations are the consequence of two developments: the increase in the $\mathrm{pH}$ of the solution originated with the addition of $\mathrm{KOH}$ and the presence of $\mathrm{CH}_{3} \mathrm{OH}$ in the feed. Basic $\mathrm{pHs}$ favour route $\mathrm{C}$ over $\mathrm{A}$; however, the presence of $\mathrm{CH}_{3} \mathrm{OH}$ in the solution might shift the advancement of the reactions involved in route $\mathrm{C}$ towards the formation of 2-oxopropanal via dehydration. This latter compound can subsequently be hydrogenated to produce propane-1,2-diol since a basic a $\mathrm{pH}$ also favours $\mathrm{H}_{2}$ production and aids hydrogenation reactions. This route has also been reported to occur at basic pHs [4]. It therefore explains the increase in the proportion of propane-1,2-diol, the decrease in the proportion of 1hydroxypropan-2-one and the steady evolution of $\mathrm{CH}_{3} \mathrm{OH}$ in the liquid product with the addition of $\mathrm{KOH}$ to the initial 3 wt. $\% \mathrm{CH}_{3} \mathrm{COOH}, 5$ wt. $\% \mathrm{CH}_{3} \mathrm{OH}, 30$ wt. $\%$ glycerol solution.

The addition of $\mathrm{CH}_{3} \mathrm{OH}$ to the binary mixture $\mathrm{CH}_{3} \mathrm{COOH}-\mathrm{KOH}$ increases the proportion of monohydric alcohols in a similar manner to that observed for the binary mixture $\mathrm{CH}_{3} \mathrm{OH}-\mathrm{CH}_{3} \mathrm{COOH}$. The increase in the proportion of $\mathrm{CH}_{3} \mathrm{OH}$ is responsible for this variation and is the consequence of its initial presence in the solution due to the low reactivity of this alcohol under the operating conditions tested. The proportions of aldehydes and C3-ketones, as in the binary mixture, and the proportion of polyhydric alcohols are not modified with the addition of $\mathrm{CH}_{3} \mathrm{OH}$ to the solution.

The comparison between Figures $8 \mathrm{a}, \mathrm{c}$, e and $\mathrm{g}$ with Figures $8 \mathrm{~b}, \mathrm{~d}$, f and h illustrates the effect of the addition of $\mathrm{CH}_{3} \mathrm{COOH}$ to the binary $\mathrm{CH}_{3} \mathrm{OH}-\mathrm{KOH}$ mixture for the 
relative amounts of monohydric and polyhydric alcohols, aldehydes and C3-ketones, respectively. This comparison reveals minor changes in the composition of the liquid phase: a small decrease in the proportion of C3-ketones together with a small increase in the relative amount of aldehydes. In addition, the comparison between the results obtained with pure glycerol and with the glycerol solution having the highest amount of the impurities considered in this work reveals similar compositions for the liquid phases with both feedstocks. Exceptionally, the liquid product obtained from the glycerol solution containing impurities has a lower amount of acetaldehyde.

\subsection{Optimal values for the concentration of the impurities to optimise the APR of crude}

\section{glycerol}

Optimal values for the concentrations of $\mathrm{CH}_{3} \mathrm{COOH}, \mathrm{CH}_{3} \mathrm{OH}$ and $\mathrm{KOH}$ in the 30 wt.\% glycerol solutions were sought making use of the experimental models developed. The predicted $\mathrm{R}^{2}$ of all the models is higher than 0.90 , allowing their use for prediction purposes. Three different optimisations were carried out. The first aims at the production of a gas with a high $\mathrm{H}_{2}$ content, and therefore comprises the maximisation of the $\mathrm{CC}$ gas, the $\mathrm{X}$ gly and the relative amount of $\mathrm{H}_{2}$ in the gas. The second and the third are directed towards valuable liquid production, thus maximising the proportions of monohydric and polyhydric alcohols, respectively, as well as the CC liq and X gly in both cases.

To meet these objectives, a solution that strikes a compromise between the optimum values for all the response variables was sought for each optimisation. To do this, a relative importance (from 1 to 5) was given to each one of the objectives in order to come up with a solution that satisfies all the criteria. To globally maximise gas and 
liquid production, a relative importance of 5 was assigned to the $\mathrm{X}$ gly, $\mathrm{CC}$ gas and $\mathrm{CC}$ liq, while a relative importance of 3 was given to the properties of the gas or liquid (vol. $\mathrm{H}_{2}$ and relative amounts of monohydric and polyhydric alcohols).

Taking these restrictions into account, the three optimisations predicted maxima for the variables considered in the absence of $\mathrm{CH}_{3} \mathrm{COOH}$ and $\mathrm{CH}_{3} \mathrm{OH}$ and with the highest amount of $\mathrm{KOH}$ considered in this work $(2.8 \mathrm{wt} . \%)$. This corresponds to the values that these impurities have in run 5. The APR results predicted in the optimisation and obtained with the statistical model (not shown) are not significantly different, with $95 \%$ confidence ( $p$-value $>0.05$ ), to those obtained in run 5 , proving the validity of the empirical model developed. This convergent solution indicates that the presence of $\mathrm{KOH}$ in the glycerol solution is beneficial for the valorisation of crude glycerol by APR. Conversely, the concentrations of $\mathrm{CH}_{3} \mathrm{COOH}$ and $\mathrm{CH}_{3} \mathrm{OH}$ in the feedstock should be reduced as much as possible in the purification step.

\section{Conclusions}

This work addresses the effects of the presence (individual, binary and ternary combinations) of up to 3 wt. $\% \mathrm{CH}_{3} \mathrm{COOH}, 5 \mathrm{wt} . \% \mathrm{CH}_{3} \mathrm{OH}$ and $2.8 \mathrm{wt} . \% \mathrm{KOH}$ on the aqueous phase reforming (APR) of a $30 \mathrm{wt} . \%$ glycerol solution at a temperature of 220 ${ }^{\circ} \mathrm{C}$ and 44 bar of pressure, with a $\mathrm{Ni}-\mathrm{La} / \mathrm{Al}_{2} \mathrm{O}_{3}$ catalyst using a $\mathrm{W} / \mathrm{m}_{\text {glycerol }}$ ratio of $25 \mathrm{~g}$ glycerol $\mathrm{min} / \mathrm{g}$ catalyst. The most relevant conclusions are summarised as follows.

1. The presence of $\mathrm{CH}_{3} \mathrm{COOH}, \mathrm{CH}_{3} \mathrm{OH}$ and $\mathrm{KOH}$ exerts a significant influence on the aqueous phase reforming (APR) of glycerol. Specifically, the presence of $\mathrm{CH}_{3} \mathrm{OH}$ in the glycerol solution decreased the X gly, CC gas and CC liq compared to the results obtained with pure glycerol. $\mathrm{CH}_{3} \mathrm{COOH}$ and $\mathrm{KOH}$ decreased and increased the $\mathrm{CC}$ gas, 
respectively, without modifying the $\mathrm{X}$ gly and $\mathrm{CC}$ liq obtained with pure glycerol. The variations observed for the $\mathrm{X}$ gly, $\mathrm{CC}$ gas and $\mathrm{CC}$ liq are the consequence of the variations in the $\mathrm{K}^{+} / \mathrm{OH}^{-}$and $\mathrm{K}^{+} / \mathrm{H}^{+}$ratios of the solutions that occur with the addition of the impurities (either alone or binary/ternary mixed) to the glycerol solution.

2. $\mathrm{KOH}$ is the impurity with the greatest influence on the gas composition, increasing the concentration of $\mathrm{H}_{2}$ and decreasing the relative amounts of $\mathrm{CO}$ and $\mathrm{CO}_{2}$ in the gas. 3. The addition of $\mathrm{CH}_{3} \mathrm{COOH}, \mathrm{CH}_{3} \mathrm{OH}$ and $\mathrm{KOH}$ to the glycerol solution significantly changes the composition of the liquid phase obtained in the APR of glycerol. The presence of $\mathrm{CH}_{3} \mathrm{OH}$ in the glycerol solution slightly changes the results obtained with glycerol alone. The proportion of this compound increases due to its initial presence in the solution and its low reactivity under the operating conditions tested. The addition of $\mathrm{CH}_{3} \mathrm{COOH}$ causes a significant decrease in the proportion of monohydric alcohols and increases the relative amount of C3-ketones. Acidic conditions promote dehydration reactions, making route A (liquid production via 1-hydroxypropan-2-one) prevalent over route $\mathrm{C}$ (liquid production via 2,3-dihydroxypropanal). The presence of up to 2.8 wt.\% of $\mathrm{KOH}$ alone in the glycerol solution does not significantly influence the composition of the liquid phase. Only a small reduction in the amount of aldehydes was observed.

4. When two or more impurities are present together in the glycerol solution (binary and ternary mixtures), other reactions between the impurities such as neutralisation and esterification can occur prior to or during the reforming reactions. This modifies the $\mathrm{K}^{+} / \mathrm{OH}^{-}$and $\mathrm{K}^{+} / \mathrm{H}^{+}$ratios and the $\mathrm{pH}$ of the solutions, thus varying the effects that these impurities exert alone.

5. Part of the active phase ( $\mathrm{Ni}$ and $\mathrm{La}$ ) and the support (Al) of the catalyst were lost by leaching during the APR reaction in some experiments. The loss of La by leaching was 
favoured under acidic conditions and might be responsible for the deactivation of the catalyst under the operating conditions tested. Basic conditions favoured Al leaching from the catalyst support, but the activity of the catalyst was unaffected.

\section{Acknowledgements}

The authors wish to express their gratitude to the Aragon Government (GPT group), European Social Fund and the Spanish MINECO (projects ENE2010-18985 and ENE2013-41523-R) for providing financial support. The authors would also like to acknowledge the use of the Servicio General de Apoyo a la Investigación-SAI of the Universidad de Zaragoza. In addition, Javier Remón Núñez would like to express his gratitude to the Spanish MINECO for the FPI grant (BES- 2011-044856) awarded. 


\section{REFERENCES}

[1] D.A. Bulushev, J.R.H. Ross, Catalysis for conversion of biomass to fuels via pyrolysis and gasification: A review, Catalysis Today 171 (2011) 1-13.

[2] J.C. Escobar, E.S. Lora, O.J. Venturini, E.E. Yáñez, E.F. Castillo, O. Almazan, Biofuels: Environment, technology and food security, Renewable and Sustainable Energy Reviews 13 1275-1287.

[3] R. Manosak, S. Limpattayanate, M. Hunsom, Sequential-refining of crude glycerol derived from waste used-oil methyl ester plant via a combined process of chemical and adsorption, Fuel Processing Technology 92 (2011) 92-99.

[4] D.L. King, L. Zhang, G. Xia, A.M. Karim, D.J. Heldebrant, X. Wang, T. Peterson, Y. Wang, Aqueous phase reforming of glycerol for hydrogen production over Pt-Re supported on carbon, Applied Catalysis B: Environmental 99 (2010) 206-213.

[5] Y.-C. Lin, Catalytic valorization of glycerol to hydrogen and syngas, International Journal of Hydrogen Energy 38 (2013) 2678-2700.

[6] M. Metsoviti, K. Paraskevaidi, A. Koutinas, A.-P. Zeng, S. Papanikolaou, Production of 1,3-propanediol, 2,3-butanediol and ethanol by a newly isolated Klebsiella oxytoca strain growing on biodiesel-derived glycerol based media, Process Biochemistry 47 (2012) 1872-1882.

[7] Z. Yuan, J. Wang, L. Wang, W. Xie, P. Chen, Z. Hou, X. Zheng, Biodiesel derived glycerol hydrogenolysis to 1,2-propanediol on $\mathrm{Cu} / \mathrm{MgO}$ catalysts, Bioresource Technology 101 (2010) 7099-7103.

[8] D.A. Boga, F. Liu, P.C.A. Bruijnincx, B.M. Weckhuysen, Aqueous-phase reforming of crude glycerol: effect of impurities on hydrogen production, Catalyst Science and Technoly (2015).

[9] K. Lehnert, P. Claus, Influence of Pt particle size and support type on the aqueousphase reforming of glycerol, Catalysis Communications 9 (2008) 2543-2546.

[10] A. Iriondo, J.F. Cambra, V.L. Barrio, M.B. Guemez, P.L. Arias, M.C. Sanchez-

Sanchez, R.M. Navarro, J.L.G. Fierro, Glycerol liquid phase conversion over monometallic and bimetallic catalysts: Effect of metal, support type and reaction temperatures, Applied Catalysis B: Environmental (2011).

[11] A.O. Menezes, M.T. Rodrigues, A. Zimmaro, L.E.P. Borges, M.A. Fraga, Production of renewable hydrogen from aqueous-phase reforming of glycerol over Pt catalysts supported on different oxides, Renewable Energy 36 (2011) 595-599. [12] D.Ö. Özgür, B.Z. Uysal, Hydrogen production by aqueous phase catalytic reforming of glycerine, Biomass and Bioenergy 35 (2011) 822-826.

[13] J.W. Shabaker, G.W. Huber, J.A. Dumesic, Aqueous-phase reforming of oxygenated hydrocarbons over Sn-modified Ni catalysts, Journal of Catalysis 222 (2004) 180-191.

[14] G. Wen, Y. Xu, H. Ma, Z. Xu, Z. Tian, Production of hydrogen by aqueous-phase reforming of glycerol, International Journal of Hydrogen Energy 33 (2008) 6657-6666. [15] Y. Guo, X. Liu, M.U. Azmat, W. Xu, J. Ren, Y. Wang, G. Lu, Hydrogen production by aqueous-phase reforming of glycerol over Ni-B catalysts, International Journal of Hydrogen Energy 37 (2012) 227-234.

[16] N. Luo, K. Ouyang, F. Cao, T. Xiao, Hydrogen generation from liquid reforming of glycerin over Ni-Co bimetallic catalyst, Biomass and Bioenergy 34 (2010) 489-495. 
[17] R.L. Manfro, A.F. da Costa, N.F.P. Ribeiro, M.M.V.M. Souza, Hydrogen production by aqueous-phase reforming of glycerol over nickel catalysts supported on $\mathrm{CeO}_{2}$, Fuel Processing Technology 92 (2011) 330-335.

[18] J. Shabaker, Aqueous-phase reforming of methanol and ethylene glycol over alumina-supported platinum catalysts, Journal of Catalysis 215 (2003) 344-352. [19] D. Roy, B. Subramaniam, R.V. Chaudhari, Aqueous phase hydrogenolysis of glycerol to 1,2-propanediol without external hydrogen addition, Catalysis Today 156 (2010) 31-37.

[20] M.M. Rahman, H2 production from aqueous-phase reforming of glycerol over $\mathrm{Cu}-$ Ni bimetallic catalysts supported on carbon nanotubes, International Journal of Hydrogen Energy 40 (2015) 14833-14844.

[21] N. Luo, X. Fu, F. Cao, T. Xiao, P.P. Edwards, Glycerol aqueous phase reforming for hydrogen generation over Pt catalyst - Effect of catalyst composition and reaction conditions, Fuel 87 (2008) 3483-3489.

[22] A. Seretis, P. Tsiakaras, Hydrogenolysis of glycerol to propylene glycol by in situ produced hydrogen from aqueous phase reforming of glycerol over $\mathrm{SiO}_{2}-\mathrm{Al}_{2} \mathrm{O}_{3}$ supported nickel catalyst, Fuel Processing Technology 142 (2016) 135-146.

[23] M. Slinn, K. Kendall, C. Mallon, J. Andrews, Steam reforming of biodiesel byproduct to make renewable hydrogen, Bioresource Technology 99 (2008) 5851-5858. [24] B. Dou, G.L. Rickett, V. Dupont, P.T. Williams, H. Chen, Y. Ding, M. Ghadiri, Steam reforming of crude glycerol with in situ $\mathrm{CO}_{2}$ sorption, Bioresource Technology 101 (2010) 2436-2442.

[25] T. Valliyappan, D. Ferdous, N.N. Bakhshi, A.K. Dalai, Production of Hydrogen and Syngas via Steam Gasification of Glycerol in a Fixed-Bed Reactor, Topics in Catalysis 49 (2008) 59-67.

[26] J. Remón, V. Mercado, L. García, J. Arauzo, Effect of acetic acid, methanol and potassium hydroxide on the catalytic steam reforming of glycerol: Thermodynamic and experimental study, Fuel Processing Technology 138 (2015) 325-336.

[27] A.G. Chakinala, W.P.M. van Swaaij, S.R.A. Kersten, D. de Vlieger, K. Seshan, D.W.F. Brilman, Catalytic Reforming of Glycerol in Supercritical Water over Bimetallic Pt-Ni Catalyst, Industrial and Engineering Chemistry Research 52 (2013) 5302-5312.

[28] M.S. Ardi, M.K. Aroua, N.A. Hashim, Progress, prospect and challenges in glycerol purification process: A review, Renewable and Sustainable Energy Reviews 42 (2015) 1164-1173.

[29] M. Ayoub, A.Z. Abdullah, Critical review on the current scenario and significance of crude glycerol resulting from biodiesel industry towards more sustainable renewable energy industry, Renewable and Sustainable Energy Reviews 16 (2012) 2671-2686. [30] A. Valiente, J.A. Medrano, M. Oliva, J. Ruiz, L. Garcia, J. Arauzo, Bioenergy II: Hydrogen Production by Aqueous-Phase Reforming, International Journal of Chemical Reactor Engineering 8 (2010).

[31] M. Hajek, F. Skopal, Treatment of glycerol phase formed by biodiesel production, Bioresource technology 101 (2010) 3242-3245.

[32] S.N. Delgado, D. Yap, L. Vivier, C. Especel, Influence of the nature of the support on the catalytic properties of Pt-based catalysts for hydrogenolysis of glycerol, Journal of Molecular Catalysis A: Chemical 367 (2013) 89-98.

[33] I. Gandarias, P.L. Arias, J. Requies, M.B. Güemez, J.L.G. Fierro, Hydrogenolysis of glycerol to propanediols over a Pt/ASA catalyst: The role of acid and metal sites on product selectivity and the reaction mechanism, Applied Catalysis B: Environmental 97 (2010) 248-256. 
[34] A. Wawrzetz, B. Peng, A. Hrabar, A. Jentys, A.A. Lemonidou, J.A. Lercher, Towards understanding the bifunctional hydrodeoxygenation and aqueous phase reforming of glycerol, Journal of Catalysis 269 (2010) 411-420.

[35] L. Zhang, A.M. Karim, M.H. Engelhard, Z. Wei, D.L. King, Y. Wang, Correlation of Pt-Re surface properties with reaction pathways for the aqueous-phase reforming of glycerol, Journal of Catalysis 287 (2012) 37-43.

[36] C. Font Palma, A.D. Martin, Inorganic constituents formed during small-scale gasification of poultry litter: A model based study, Fuel Processing Technology 116 (2013) 300-307.

[37] P. Nanou, H.E. Gutiérrez Murillo, W.P.M. van Swaaij, G. van Rossum, S.R.A. Kersten, Intrinsic reactivity of biomass-derived char under steam gasification conditions-potential of wood ash as catalyst, Chemical Engineering Journal 217 (2013) 289-299.

[38] R.H. Perry, D.W. Green, Perry's Chemical Engineers' Handbook, McGraw-Hill, New York, 2008.

[39] J. Remón, J.A. Medrano, F. Bimbela, L. García, J. Arauzo, Ni/Al-Mg-O solids modified with $\mathrm{Co}$ or $\mathrm{Cu}$ for the catalytic steam reforming of bio-oil, Applied Catalysis B: Environmental 132-133 (2013) 433-444.

[40] H. Al-Sheeha, M. Marafi, A. Stanislaus, Reclamation of alumina as boehmite from an alumina-supported spent catalyst, International Journal of Mineral Processing 88 (2008) 59-64.

[41] M.C. Martín-Torre, G. Ruiz, B. Galán, J.R. Viguri, Generalised mathematical model to estimate $\mathrm{Zn}, \mathrm{Pb}, \mathrm{Cd}, \mathrm{Ni}, \mathrm{Cu}, \mathrm{Cr}$ and As release from contaminated estuarine sediment using pH-static leaching tests, Chemical Engineering Science 138 (2015) 780790.

[42] L. Meng, J. Qu, Q. Guo, K. Xie, P. Zhang, L. Han, G. Zhang, T. Qi, Recovery of $\mathrm{Ni}, \mathrm{Co}, \mathrm{Mn}$, and $\mathrm{Mg}$ from nickel laterite ores using alkaline oxidation and hydrochloric acid leaching, Separation and Purification Technology 143 (2015) 80-87.

[43] T. van Haasterecht, C.C.I. Ludding, K.P. de Jong, J.H. Bitter, Toward stable nickel catalysts for aqueous phase reforming of biomass-derived feedstock under reducing and alkaline conditions, Journal of Catalysis 319 (2014) 27-35.

[44] H.N. Pham, Y.J. Pagan-Torres, J.C. Serrano-Ruiz, D. Wang, J.A. Dumesic, A.K. Datye, Improved hydrothermal stability of niobia-supported Pd catalysts, Applied Catalysis A: General 397 (2011) 153-162.

[45] E.S. Vasiliadou, V.L. Yfanti, A.A. Lemonidou, One-pot tandem processing of glycerol stream to 1,2-propanediol with methanol reforming as hydrogen donor reaction, Applied Catalysis B: Environmental 163 (2015) 258-266.

[46] D.G. Lahr, B.H. Shanks, Kinetic Analysis of the Hydrogenolysis of Lower Polyhydric Alcohols: Glycerol to Glycols, Industrial \& Engineering Chemistry Research 42 (2003) 5467-5472.

[47] A. Casas, C.M. Fernández, M.J. Ramos, Á. Pérez, J.F. Rodríguez, Optimization of the reaction parameters for fast pseudo single-phase transesterification of sunflower oil, Fuel 89 (2010) 650-658.

[48] R.R. Davda, J.W. Shabaker, G.W. Huber, R.D. Cortright, J.A. Dumesic, A review of catalytic issues and process conditions for renewable hydrogen and alkanes by aqueous-phase reforming of oxygenated hydrocarbons over supported metal catalysts, Applied Catalysis B: Environmental 56 (2005) 171-186.

[49] T. Fujii, R. Hayashi, Y. Oshima, Analysis of acid-catalyzed dehydration of formic acid in hot compressed water based on density functional theory, The Journal of Supercritical Fluids 84 (2013) 190-194. 
[50] T. Borowiecki, A. Denis, M. Rawski, A. Gołębiowski, K. Stołecki, J. Dmytrzyk, A. Kotarba, Studies of potassium-promoted nickel catalysts for methane steam reforming: Effect of surface potassium location, Applied Surface Science 300 (2014) 191-200.

[51] B.M. Nagaraja, D.A. Bulushev, S. Beloshapkin, J.R.H. Ross, The effect of potassium on the activity and stability of $\mathrm{Ni}-\mathrm{MgO}-\mathrm{ZrO}_{2}$ catalysts for the dry reforming of methane to give synthesis gas, Catalysis Today 178 (2011) 132-136.

[52] M.A. Dasari, P.-P. Kiatsimkul, W.R. Sutterlin, G.J. Suppes, Low-pressure hydrogenolysis of glycerol to propylene glycol, Applied Catalysis A: General 281 (2005) 225-231.

[53] T. Miyazawa, S. Koso, K. Kunimori, K. Tomishige, Development of a Ru/C catalyst for glycerol hydrogenolysis in combination with an ion-exchange resin, Applied Catalysis A: General 318 (2007) 244-251.

[54] T. Miyazawa, Y. Kusunoki, K. Kunimori, K. Tomishige, Glycerol conversion in the aqueous solution under hydrogen over $\mathrm{Ru} / \mathrm{C}+$ an ion-exchange resin and its reaction mechanism, Journal of Catalysis 240 (2006) 213-221. 


\section{TABLES}

Table 1. Response variables. Definitions and analytical techniques used in their determination.

\begin{tabular}{|c|c|c|}
\hline Product & Response variable & Analytical method \\
\hline Gas & $\begin{array}{c}\text { CC gas }(\%)=\frac{\mathrm{C} \text { in the gas }(\mathrm{g})}{\mathrm{C} \text { fed }(\mathrm{g})} 100 \\
\text { Composition }(\text { vol. } \%)=\frac{\text { mol of each gas }}{\text { total mol of gas }} 100\end{array}$ & $\begin{array}{l}\text { Micro Gas Chromatograph (Micro } \\
\text { GC). } \mathrm{N}_{2} \text { as internal standard } \\
\text { Online analyses }\end{array}$ \\
\hline \multirow{4}{*}{ Liquid } & CC liq $(\%)=\frac{\text { C in the liquid products }(\mathrm{g})}{\mathrm{C} \text { fed }(\mathrm{g})} 100$ & Total Organic Carbon (TOC) \\
\hline & Composition $($ area $\%)=\frac{\text { area of each compound }}{\text { total area }} 100$ & $\begin{array}{c}\text { GC-MS (Gas Chromatography- } \\
\text { Mass Spectrometry) }\end{array}$ \\
\hline & $\mathrm{X}$ gly $(\%)=\frac{\text { glycerol fed }(\mathrm{g})-\text { glycerol in the liquid }(\mathrm{g})}{\text { glycerol fed }(\mathrm{g})} 100$ & $\begin{array}{c}\text { GC-FID (Gas Chromatography- } \\
\text { Flame ionization detector) }\end{array}$ \\
\hline & & Offline analyses \\
\hline
\end{tabular}

Table 2. Concentration (wt.\%) of acetic acid, methanol potassium hydroxide (expressed in codec and actual values), $\mathrm{pH}$ (mean \pm standard deviation) and water/carbon (W/C) ratio of the $30 \mathrm{wt} . \%$ glycerol solutions

\begin{tabular}{|c|c|c|c|c|c|c|c|c|}
\hline \multirow[t]{2}{*}{ Run } & \multicolumn{2}{|c|}{$\begin{array}{c}{\left[\mathrm{CH}_{3} \mathrm{COOH}\right]} \\
(\text { wt. } \%)\end{array}$} & \multicolumn{2}{|c|}{$\begin{array}{c}{\left[\mathrm{CH}_{3} \mathrm{OH}\right]} \\
\text { (wt.\%) }\end{array}$} & \multicolumn{2}{|c|}{$\begin{array}{l}\text { [KOH] } \\
\text { (wt.\%) }\end{array}$} & \multirow[t]{2}{*}{$\mathrm{pH}$} & \multirow[t]{2}{*}{$\begin{array}{c}\mathrm{W} / \mathrm{C} \\
\left(\mathrm{mol} \mathrm{H}{ }_{2} \mathrm{O} / \mathrm{mol} \mathrm{C}\right)\end{array}$} \\
\hline & Codec & Actual & Codec & Actual & Codec & Actual & & \\
\hline 1 & -1 & 0 & -1 & 0 & -1 & 0 & $5.76 \pm 0.22$ & 3.98 \\
\hline 2 & 1 & 3 & -1 & 0 & -1 & 0 & $2.46 \pm 0.06$ & 3.45 \\
\hline 3 & -1 & 0 & 1 & 5 & -1 & 0 & $6.46 \pm 0.30$ & 3.18 \\
\hline 4 & 1 & 3 & 1 & 5 & -1 & 0 & $2.53 \pm 0.22$ & 2.79 \\
\hline 5 & -1 & 0 & -1 & 0 & 1 & 2.8 & $13.29 \pm 0.41$ & 3.82 \\
\hline 6 & 1 & 3 & -1 & 0 & 1 & 2.8 & $11.84 \pm 0.31$ & 3.31 \\
\hline 7 & -1 & 0 & 1 & 5 & 1 & 2.8 & $13.40 \pm 0.47$ & 3.05 \\
\hline 8 & 1 & 3 & 1 & 5 & 1 & 2.8 & $11.93 \pm 0.37$ & 2.66 \\
\hline $9,10,11$ & 0 & 1.5 & 0 & 2.5 & 0 & 1.4 & $6.50 \pm 0.06$ & 3.24 \\
\hline
\end{tabular}


Table 3. Percentage of active phase metals leached and numerical decay for the glycerol conversion

\begin{tabular}{|c|c|c|c|c|}
\hline Run & Ni leached (\%) & Al leached (\%) & La leached (\%) & Loss in X gly (\%) \\
\hline 1 & $0.067^{\mathrm{B}}$ & $0.012^{\mathrm{B}}$ & $9.70^{\mathrm{B}}$ & 16 \\
\hline 4 & $0.152^{\mathrm{A}}$ & $0.006^{\mathrm{B}}$ & $46.96^{\mathrm{A}}$ & 18 \\
\hline 5 & $0.012^{\mathrm{C}}$ & $1.479^{\mathrm{A}}$ & $0.01^{\mathrm{C}}$ & 0 \\
\hline 6 & $0.08^{\mathrm{C}}$ & $0.010^{\mathrm{B}}$ & $1.81^{\mathrm{C}}$ & 5 \\
\hline $9,10,11$ & $0.0065 \pm 0.02^{\mathrm{C}}$ & $0.025 \pm 0.03^{\mathrm{B}}$ & $3.27 \pm 0.27^{\mathrm{C}}$ & 0 \\
\hline $\mathrm{p}$-value & 0.024 & 0.034 & 0.014 & \\
\hline
\end{tabular}

$\mathrm{A}, \mathrm{B}$ and $\mathrm{C}$ in each column represents statistically significant groups with $95 \%$ confidence

Table 4. Relative influence of the impurities on the $\mathrm{X}$ gly, $\mathrm{CC}$ gas and $\mathrm{CC}$ liq during the first hour of experiment according to the ANOVA analysis

\begin{tabular}{|c|c|c|c|c|c|c|c|c|c|}
\hline Response & $\mathbf{R}^{2}$ & Intercept & AcH & MeOH & KOH & AcH *MeOH & $\mathbf{A c H} * \mathbf{K O H}$ & MeOH * KOH & $\mathrm{AcH} * \mathrm{MeOH} * \mathrm{KOH}$ \\
\hline X gly $(\%)($ & 0.93 & 76.59 & $\begin{array}{c}-2.69 \\
(13)\end{array}$ & $\begin{array}{c}-7.28 \\
(34)\end{array}$ & $\begin{array}{c}-3.96 \\
(19)\end{array}$ & $\begin{array}{l}3.79 \\
(18)\end{array}$ & $\begin{array}{c}-3.38 \\
(16)\end{array}$ & $\mathrm{ns}$ & $\mathrm{ns}$ \\
\hline $\mathrm{CC}$ gas $(\%)$ & 0.96 & 18.00 & $\begin{array}{c}-1.92 \\
(17)\end{array}$ & $\begin{array}{l}-3.70 \\
(32)\end{array}$ & $\begin{array}{l}1.39 \\
(12)\end{array}$ & $\begin{array}{l}2.45 \\
(21)\end{array}$ & ns & $\begin{array}{l}2.00 \\
(17)\end{array}$ & ns \\
\hline CC liq (\%) & 0.95 & 56.49 & $\begin{array}{l}-2.15 \\
(12)\end{array}$ & $\begin{array}{l}-4.16 \\
(22)\end{array}$ & $\begin{array}{c}-2.36 \\
(13)\end{array}$ & $\begin{array}{l}3.39 \\
(18)\end{array}$ & $\begin{array}{c}-4.32 \\
(23)\end{array}$ & ns & $\begin{array}{l}2.19 \\
(12)\end{array}$ \\
\hline
\end{tabular}

${ }^{\text {ns }}$ Not significant with $95 \%$ confidence

Response $=$ Intercept $+\mathrm{AcH}$ coefficient $*[\mathrm{AcH}]+\mathrm{MeOH}$ coefficient $*[\mathrm{MeOH}]+\mathrm{KOH}$ coefficient $*[\mathrm{KOH}]+\mathrm{AcH} * \mathrm{MeOH}$ coefficient $*[\mathrm{AcH}]^{*}[\mathrm{MeOH}]+\mathrm{AcH}^{*} \mathrm{KOH}$ coefficient $*[\mathrm{AcH}]^{*}[\mathrm{KOH}]+\mathrm{AcH} * \mathrm{MeOH}^{*} \mathrm{KOH}$ coefficient $*[\mathrm{AcH}]^{*}$ $[\mathrm{MeOH}] *[\mathrm{KOH}]$

Numbers in brackets indicate the percentage Pareto influence of each factor on the response variable. Pareto values represent the percentage of the orthogonal estimated total value

Table 5. Relative influence of the impurities on the gas composition obtained during the first hour of experiment according to the ANOVA analysis

\begin{tabular}{|c|c|c|c|c|c|c|c|c|c|}
\hline Response & $\mathbf{R}^{2}$ & Intercept & $\mathbf{A c H}$ & МeOH & KOH & АсH * МeOH & $\mathbf{A c H} * \mathbf{K O H}$ & $\mathrm{MeOH} * \mathrm{KOH}$ & AcH $* \mathrm{MeOH} * \mathrm{KOH}$ \\
\hline $\mathrm{H}_{2}(\operatorname{vol} . \%)$ & 0.95 & 33.25 & $\begin{array}{l}-1.70 \\
(14)\end{array}$ & $\begin{array}{l}1.48 \\
(13)\end{array}$ & $\begin{array}{l}5.84 \\
(49)\end{array}$ & $\mathrm{ns}$ & $\begin{array}{c}-1.29 \\
(11)\end{array}$ & $\begin{array}{c}-1.59 \\
(13)\end{array}$ & $\mathrm{ns}$ \\
\hline $\mathrm{CO}_{2}($ vol.\%) & 0.97 & 44.37 & $\begin{array}{l}1.27 \\
\text { (13) }\end{array}$ & $\begin{array}{c}-0.97 \\
(10)\end{array}$ & $\begin{array}{c}-2.93 \\
(31)\end{array}$ & $\begin{array}{c}-1.52 \\
(16)\end{array}$ & $\begin{array}{l}1.15 \\
(12)\end{array}$ & $\begin{array}{l}1.58 \\
(17)\end{array}$ & ns \\
\hline CO (vol.\%) & 0.90 & 1.85 & $\begin{array}{l}0.39 \\
(16)\end{array}$ & $\begin{array}{l}0.33 \\
(14)\end{array}$ & $\begin{array}{l}-1.36 \\
(57)\end{array}$ & ns & ns & $\begin{array}{l}-0.32 \\
(13)\end{array}$ & $\mathrm{ns}$ \\
\hline $\mathrm{CH}_{4}(\mathrm{vol} . \%)$ & na & 19.34 & ns & ns & ns & ns & ns & ns & ns \\
\hline
\end{tabular}

${ }^{\text {ns }}$ Not significant with $95 \%$ confidence

na Nor analysed

Response $=$ Intercept $+\mathrm{AcH}$ coefficient $*[\mathrm{AcH}]+\mathrm{MeOH}$ coefficient $*[\mathrm{MeOH}]+\mathrm{KOH}$ coefficient $*[\mathrm{KOH}]+\mathrm{AcH} * \mathrm{MeOH}$ coefficient $*[\mathrm{AcH}] *[\mathrm{MeOH}]+\mathrm{AcH}^{*} \mathrm{KOH}$ coefficient $*[\mathrm{AcH}] *[\mathrm{KOH}]+\mathrm{AcH} * \mathrm{MeOH} * \mathrm{KOH}$ coefficient $*[\mathrm{AcH}]^{*}$ $[\mathrm{MeOH}] *[\mathrm{KOH}]$

$[\mathrm{AcH}],[\mathrm{MeOH}]$ and $[\mathrm{KOH}]$ are the concentrations of acetic acid, methanol and potassium hydroxide, respectively, in the $30 \mathrm{wt} \%$ glycerol solution expressed in codec factors (-1 to 1$)$

Numbers in brackets indicate the percentage Pareto influence of each factor on the response variable. Pareto values represent the percentage of the orthogonal estimated total value 
Table 6. Relative influence of the impurities on the liquid composition obtained during the first hour of experiment according to the ANOVA analysis

\begin{tabular}{|c|c|c|c|c|c|c|c|c|c|}
\hline Response & $\mathbf{R}^{2}$ & Intercept & AcH & МeОН & КОН & АсH *МeOH & АсH * КОН & МеОН * КОН & АcH * МeOH * КОН \\
\hline $\begin{array}{l}\text { Mono-Alcohols } \\
\text { (Area \%) }\end{array}$ & 0.90 & 24.62 & $\begin{array}{c}-2.70 \\
(32)\end{array}$ & $\begin{array}{l}2.61 \\
(31)\end{array}$ & ns & $\begin{array}{l}2.03 \\
(24)\end{array}$ & $\begin{array}{c}-1.00 \\
(12)\end{array}$ & ns & ns \\
\hline $\begin{array}{l}\text { Poly-Alcohols } \\
\text { (Area-\%) }\end{array}$ & 0.73 & 70.05 & $\begin{array}{l}0.39 \\
(32)\end{array}$ & $\begin{array}{l}-1.47 \\
(31)\end{array}$ & ns & $\begin{array}{c}-1.99 \\
(24)\end{array}$ & ns & $\begin{array}{l}3.08 \\
(12)\end{array}$ & ns \\
\hline $\begin{array}{l}\text { Aldehydes } \\
\text { (Area \%) }\end{array}$ & 0.92 & 0.75 & $\begin{array}{c}0.12 \\
18\end{array}$ & $\mathrm{~ns}$ & $\begin{array}{c}-0.30 \\
(45)\end{array}$ & $\mathrm{ns}$ & $\begin{array}{l}0.15 \\
(23)\end{array}$ & ns & $\begin{array}{l}0.09 \\
(14)\end{array}$ \\
\hline $\begin{array}{l}\text { C3-ketones } \\
\text { (Area \%) }\end{array}$ & 0.76 & 12.50 & ns & $\begin{array}{l}1.27 \\
(23)\end{array}$ & $\begin{array}{l}-2.33 \\
(47)\end{array}$ & ns & $\begin{array}{c}-1.44 \\
(30)\end{array}$ & ns & ns \\
\hline
\end{tabular}

ns Not significant with $95 \%$ confidence

Response $=$ Intercept $+\mathrm{AcH}$ coefficient $*[\mathrm{AcH}]+\mathrm{MeOH}$ coefficient $*[\mathrm{MeOH}]+\mathrm{KOH}$ coefficient $*[\mathrm{KOH}]+\mathrm{AcH} * \mathrm{MeOH}$ coefficient $*[\mathrm{AcH}] *[\mathrm{MeOH}]+\mathrm{AcH} * \mathrm{KOH}$ coefficient $*[\mathrm{AcH}]^{*}[\mathrm{KOH}]+\mathrm{AcH} \mathrm{MeOH}^{*} \mathrm{KOH}$ coefficient $*[\mathrm{AcH}] *$ $[\mathrm{MeOH}] *[\mathrm{KOH}]$

$[\mathrm{AcH}],[\mathrm{MeOH}]$ and $[\mathrm{KOH}]$ are the concentrations of acetic acid, methanol and potassium hydroxide, respectively, in the 30 wt. $\%$ glycerol solution expressed in codec factors (-1 to 1$)$

Numbers in brackets indicate the percentage Pareto influence of each factor on the response variable. Pareto values represent the percentage of the orthogonal estimated total value 


\section{FIGURES}

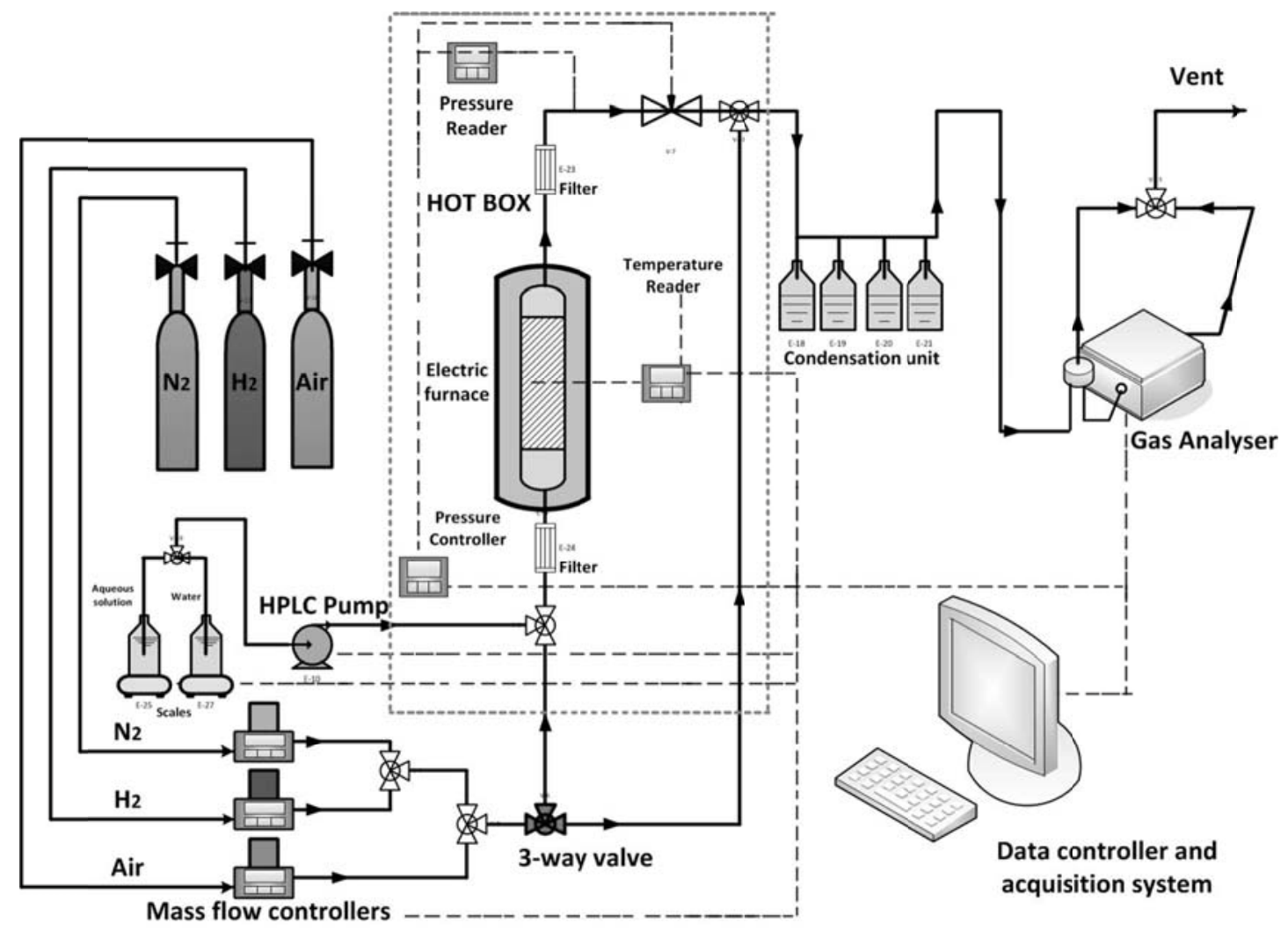

Figure 1. Schematic diagram of the aqueous phase reforming experimental rig. 

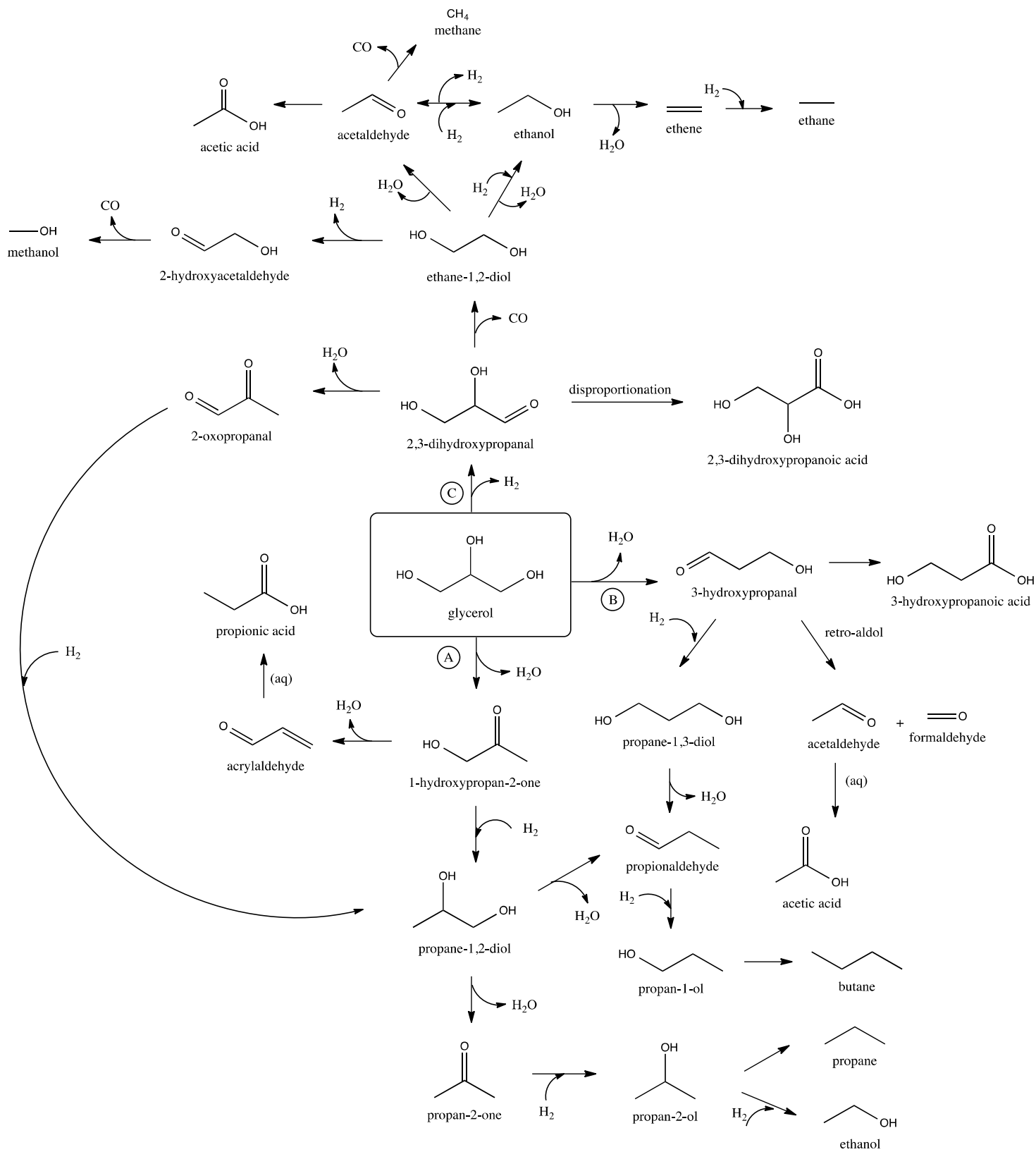

Figure 2. Possible reaction pathways during the aqueous phase reforming of glycerol. 

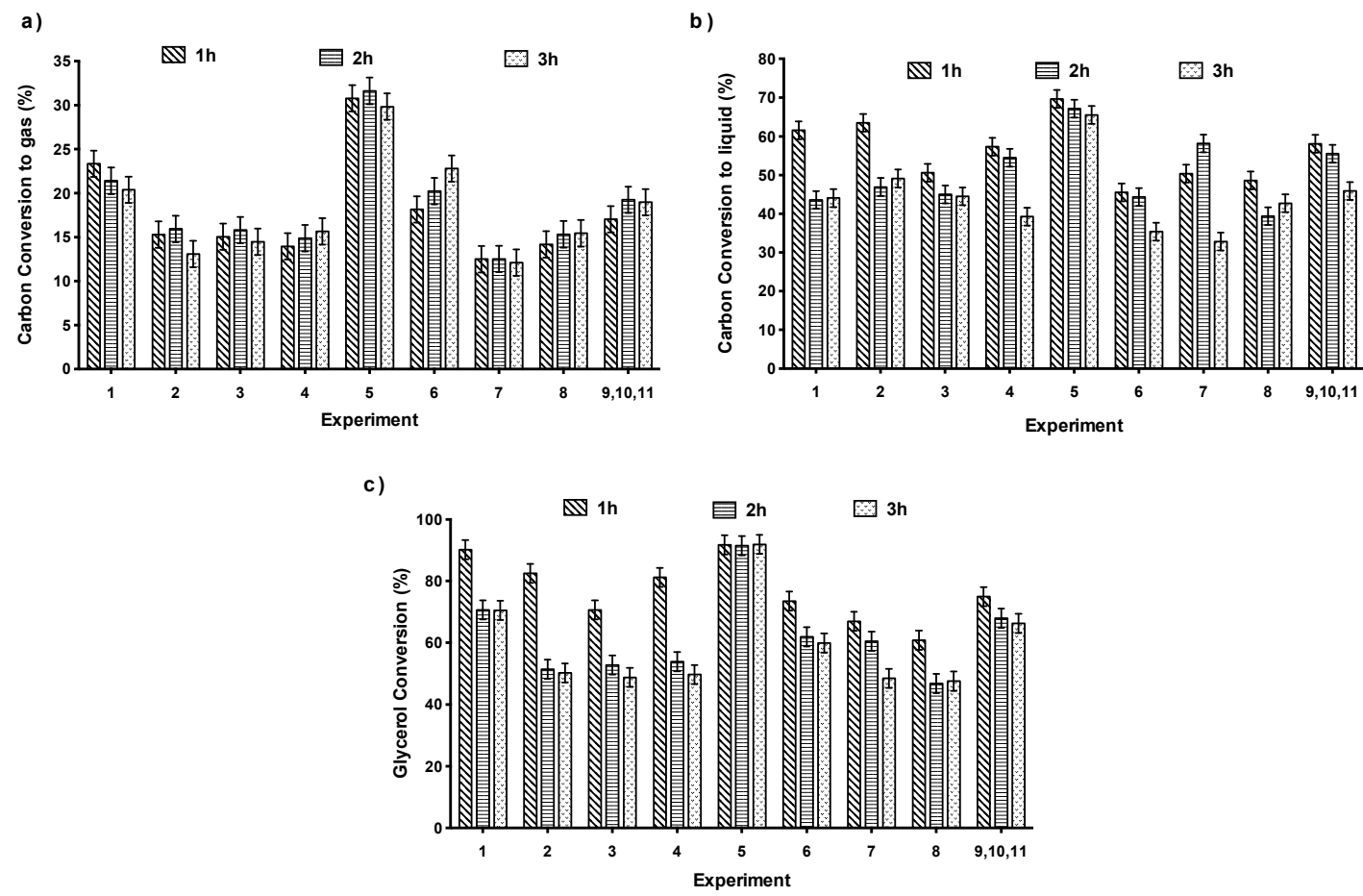

Figure 3. Conversion to gas (a), liquid (b) and global glycerol conversion (c) obtained during the APR experiments. Results are presented as the overall values obtained every 60 minutes and expressed as mean \pm 0.5 Fisher LSD intervals with $95 \%$ confidence. 
a)

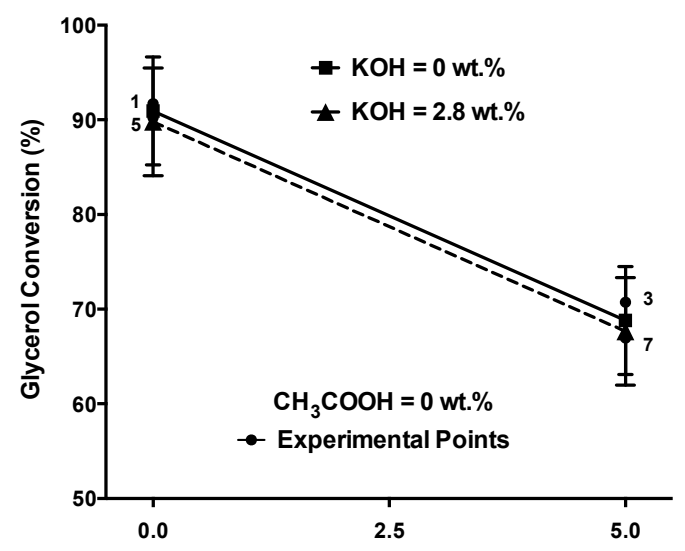

c)

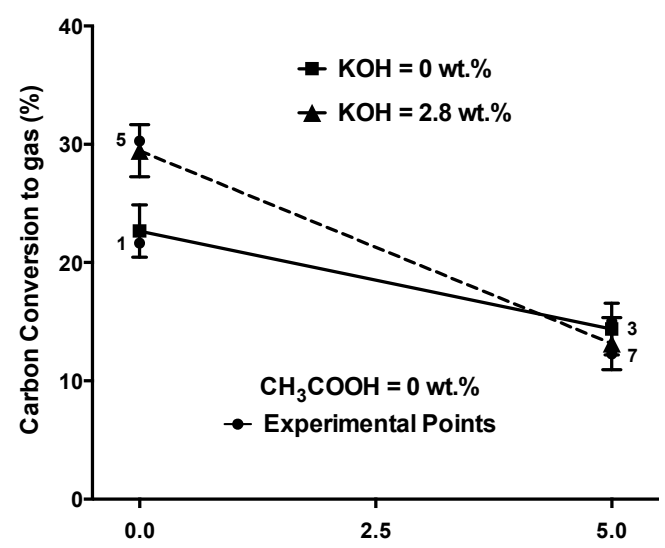

e)

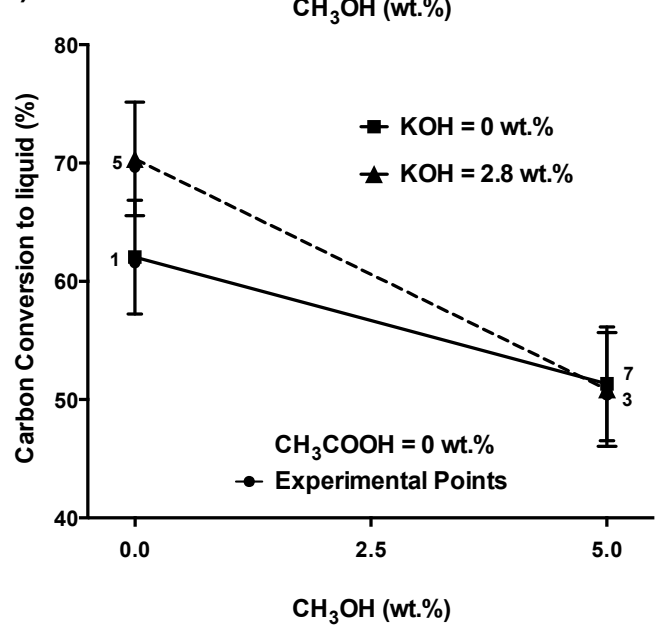

b)

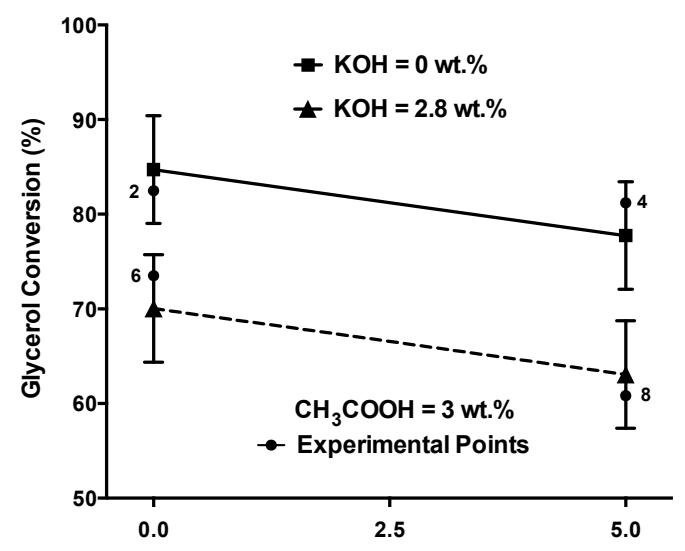

d)

$\mathrm{CH}_{3} \mathrm{OH}$ (wt.\%)

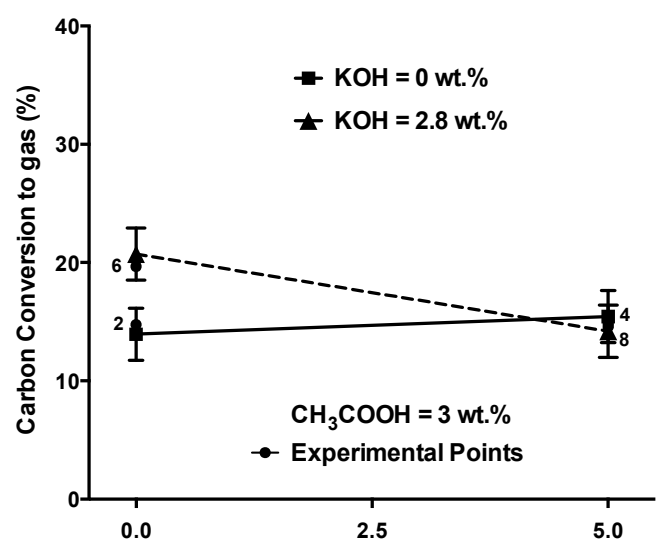

$\mathrm{CH}_{3} \mathrm{OH}$ (wt.\%)

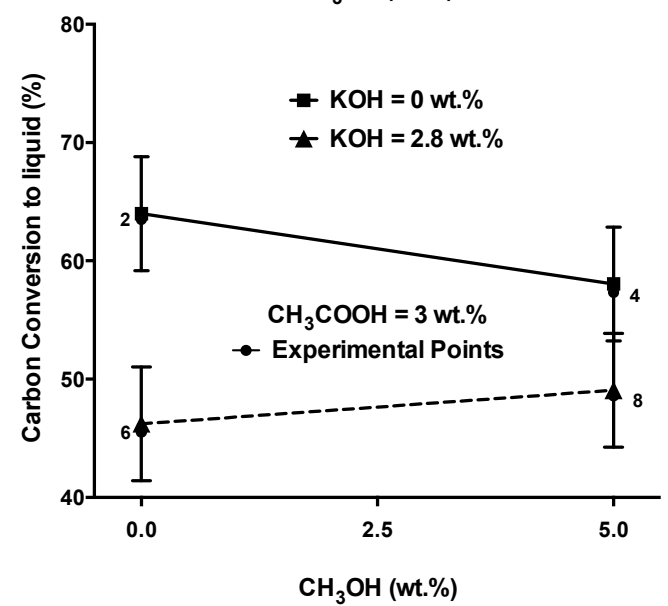

Figure 4. Interaction plots for the initial X gly ( $\mathrm{a}$ and b), CC gas ( $\mathrm{c}$ and d) and $\mathrm{CC}$ liq (e and f). Bars are LSD intervals with 95\% confidence. 

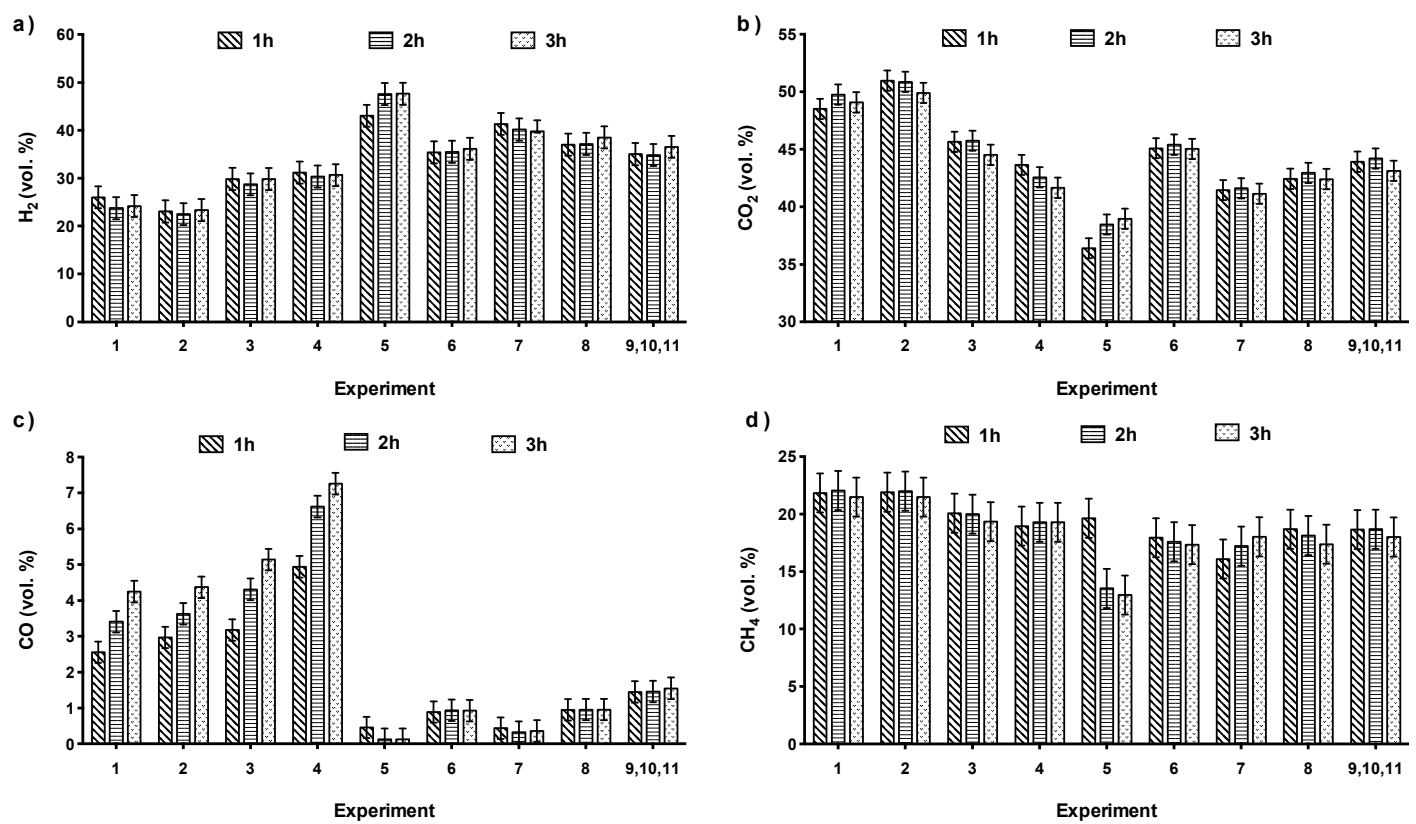

Figure 5. Relative amounts (vol.\%) of $\mathrm{H}_{2}(\mathrm{a}), \mathrm{CO}_{2}$ (b) $\mathrm{CO}$ (c) and $\mathrm{CH}_{4}$ (d) in the gas obtained during the APR experiments. Results are presented as the overall values obtained every 60 minutes and expressed as mean \pm 0.5 Fisher LSD intervals with $95 \%$ confidence. 
a)

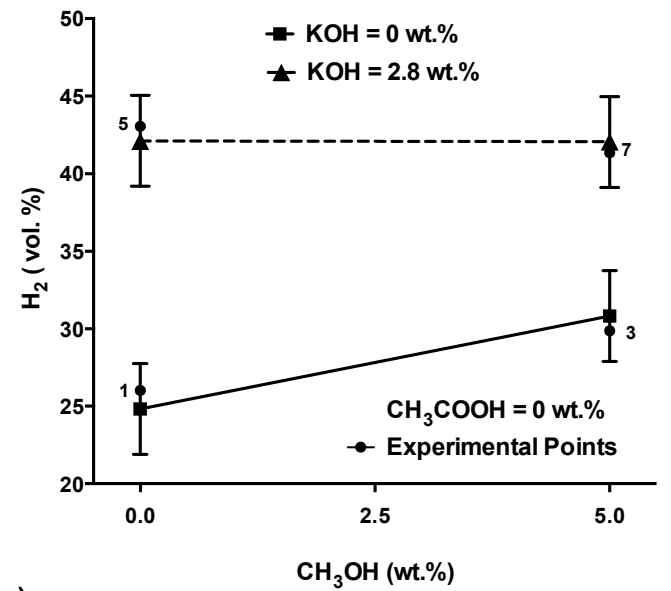

c)

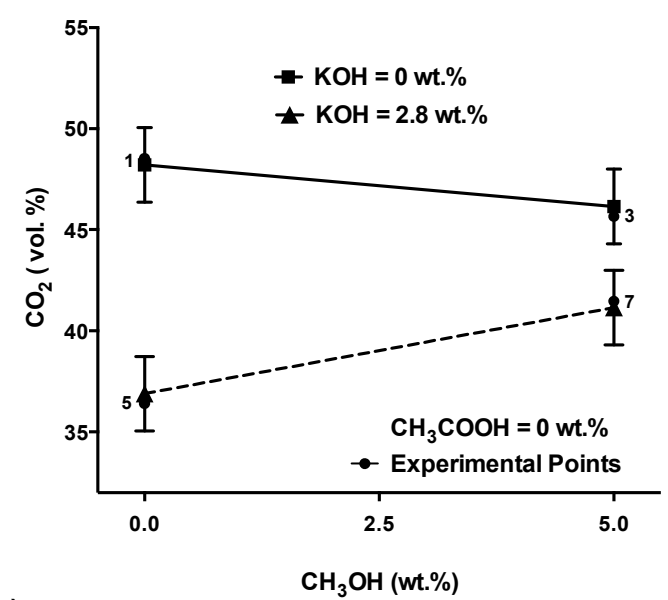

e)

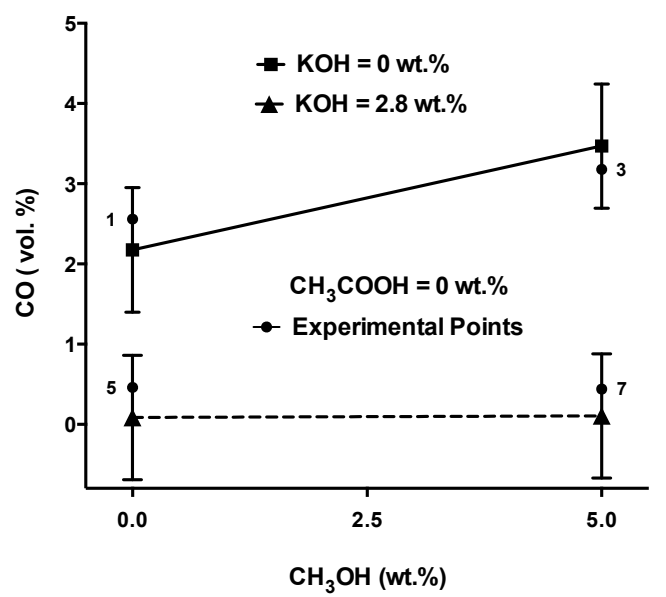

b)

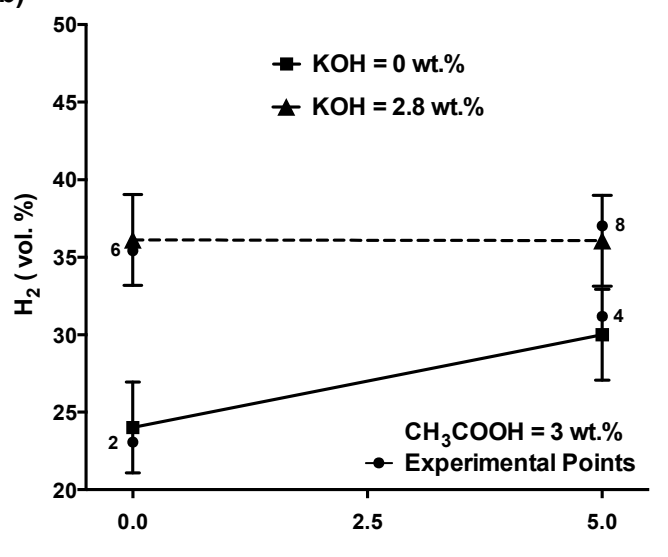

d)

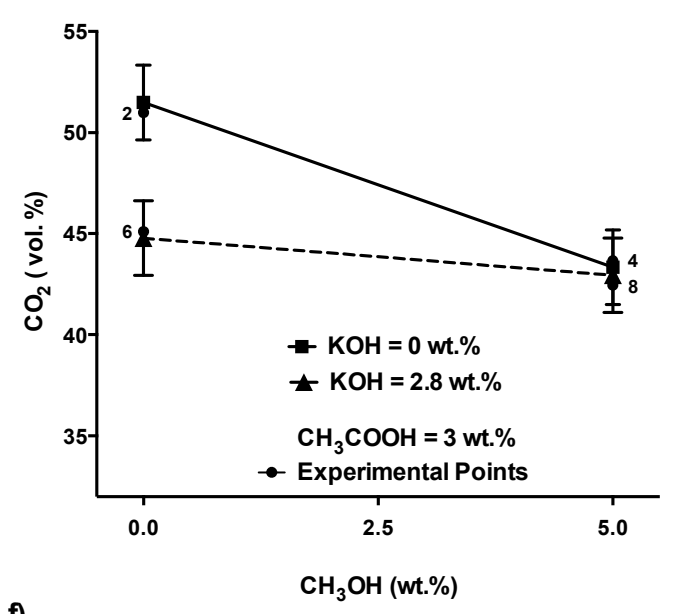

f)

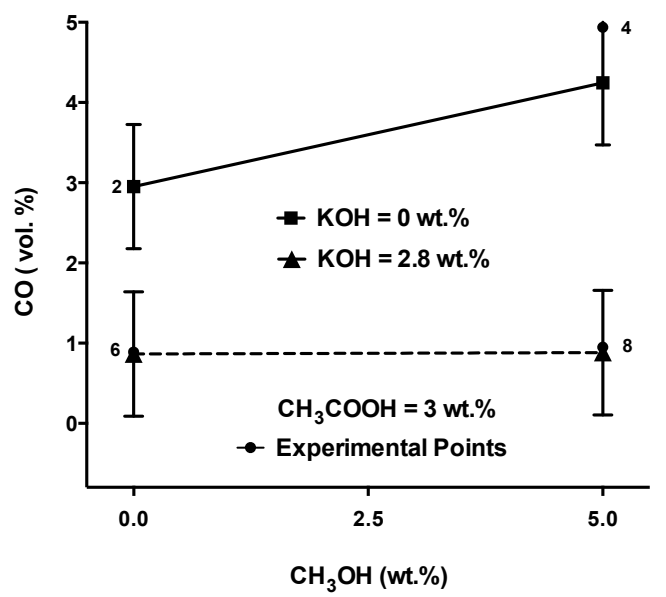

Figure 6. Interaction plots for the initial proportions of $\mathrm{H}_{2}\left(\mathrm{a}\right.$ and $\mathrm{b}$ ), $\mathrm{CO}_{2}$ (c and d) and $\mathrm{CO}$ (e and $\mathrm{f}$ ) in the gas. Bars are LSD intervals with $95 \%$ confidence. 

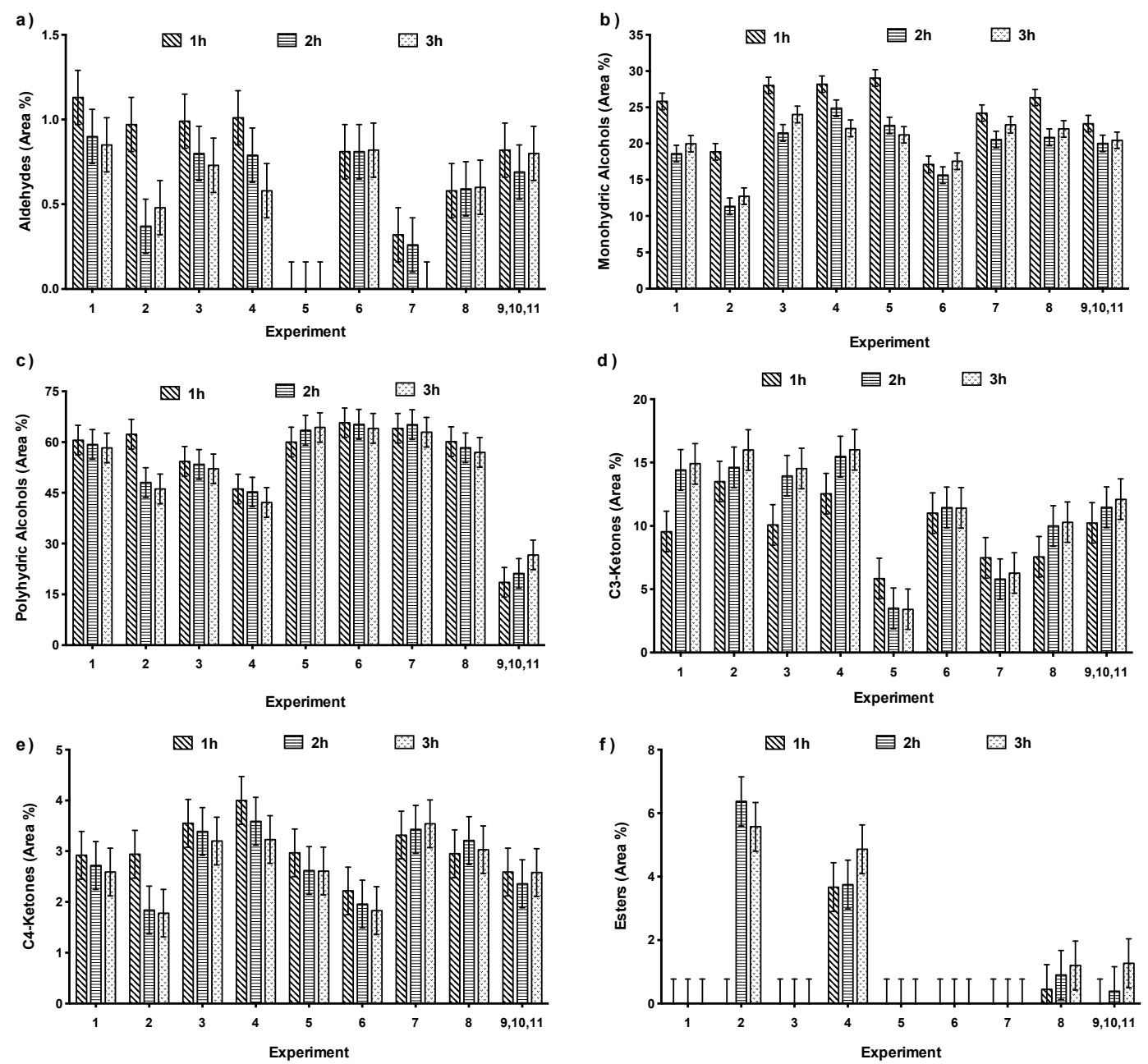

Figure 7. Proportions (\%chromatographic Area) of aldehydes (a), monohydric alcohols (b), polyhydric alcohols (c), C3-ketones (d), C4-ketones (e) and esters (f) in the liquid obtained during the APR experiments. Results are presented as the overall values obtained every 60 minutes and expressed as mean \pm 0.5 Fisher LSD intervals with $95 \%$ confidence. 
a)

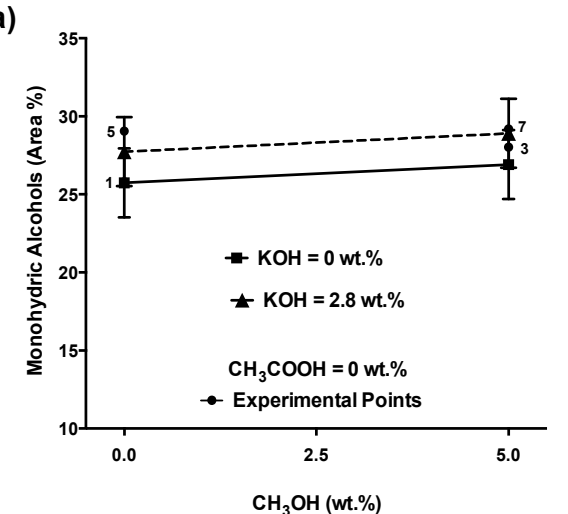

c)

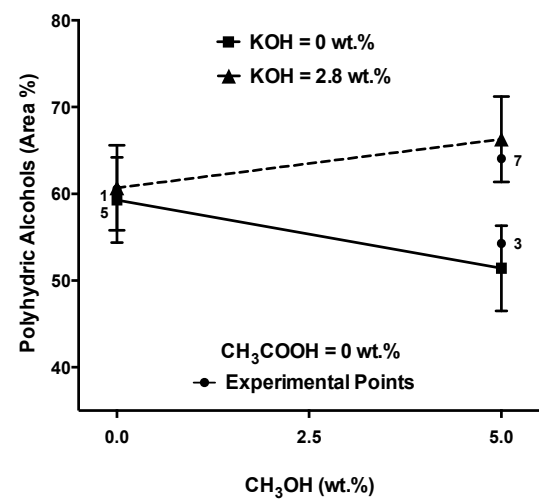

e)

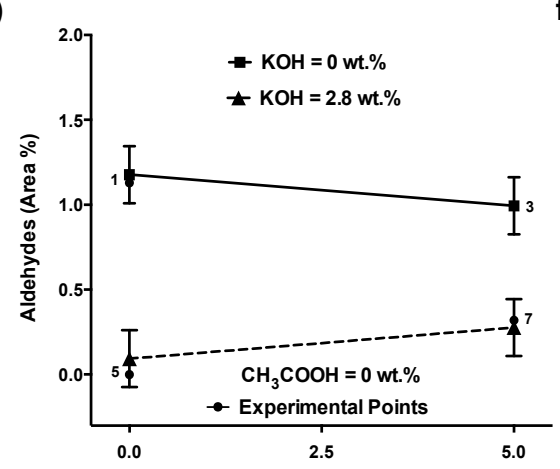

g)

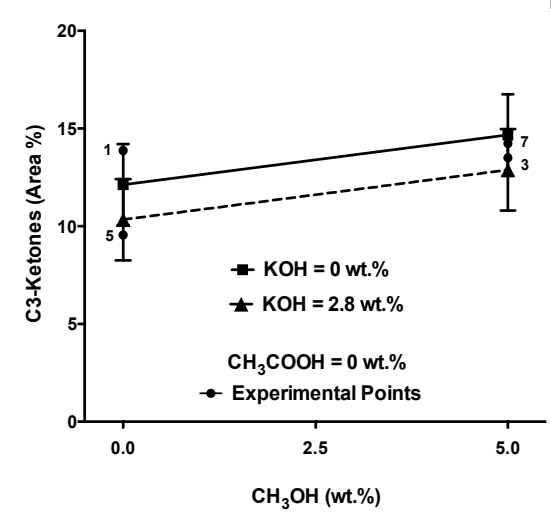

b)

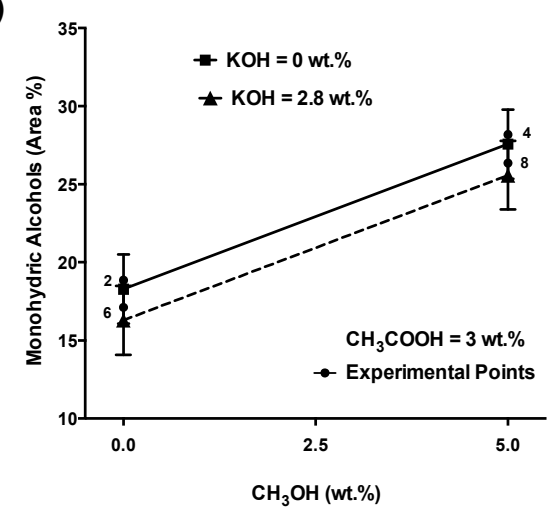

d)

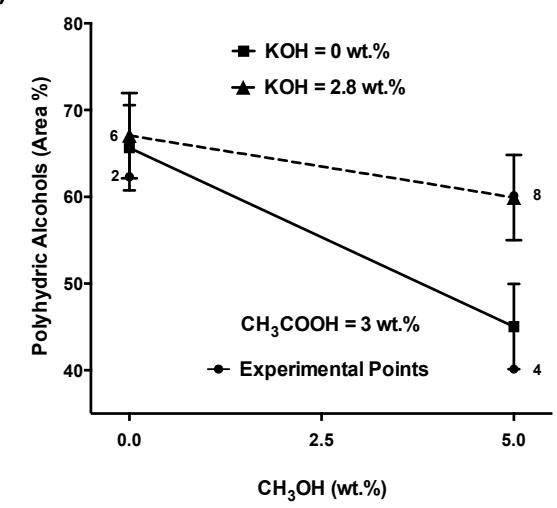

f)

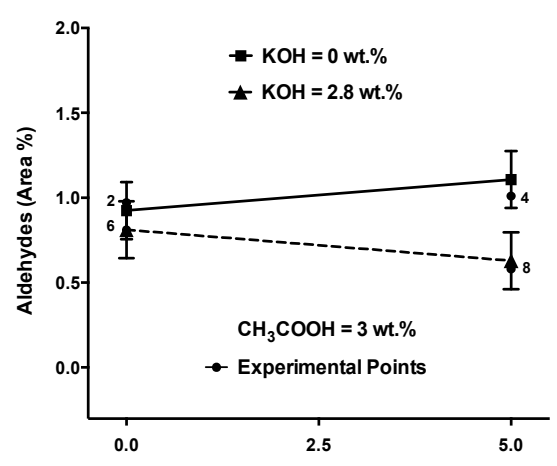

h)

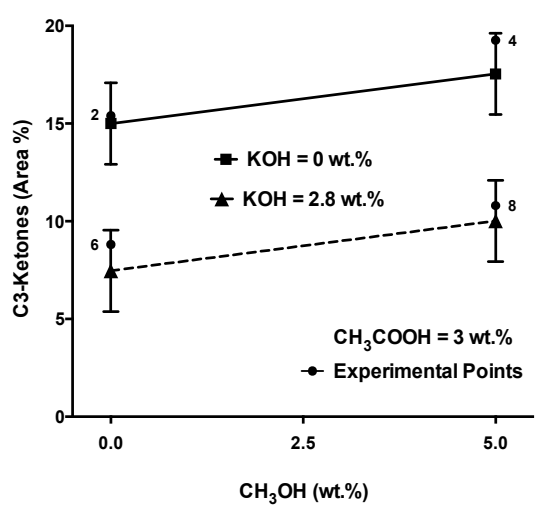

Figure 8. Interaction plots for the initial proportions of monohydric alcohols ( $a$ and $b$ ), polyhydric alcohols ( $\mathrm{c}$ and d), aldehydes (e and f) and C3-ketones ( $\mathrm{g}$ and $\mathrm{h}$ ) in the liquid product. Bars are LSD intervals with $95 \%$ confidence. 